\title{
Credit Constraints as a Barrier to the Entry and Post-Entry Growth of Firms
}

\section{Citation}

Aghion, Philippe, Thibault Fally, and Stefano Scarpetta. 2007. Credit constraints as a barrier to the entry and post-entry growth of firms. Economic Policy 22(52): 731-779.

\section{Published Version}

doi:10.1111/j.1468-0327.2007.00190.x

\section{Permanent link}

http://nrs.harvard.edu/urn-3:HUL.InstRepos:4554208

\section{Terms of Use}

This article was downloaded from Harvard University's DASH repository, and is made available under the terms and conditions applicable to Other Posted Material, as set forth at http:// nrs.harvard.edu/urn-3:HUL.InstRepos:dash.current.terms-of-use\#LAA

\section{Share Your Story}

The Harvard community has made this article openly available.

Please share how this access benefits you. Submit a story.

\section{Accessibility}




\title{
Credit Constraints as a Barrier to the Entry and Post-Entry Growth of Firms
}

\author{
Philippe Aghion, Thibault Fally, Stefano Scarpetta ${ }^{1}$
}

March, 2007

\begin{abstract}
:
Advanced market economies are characterized by a continuous process of creative destruction. Market forces and technological developments play a major role in shaping this process, but institutional and policy settings also influence firms' decision to enter, to expand if successful and to exit if competition becomes unbearable. In this paper, we focus on the effects of financial development on the entry of new firms and the expansion of successful new businesses. Drawing from harmonized firm-level data for 16 industrialized and emerging economies, we find that access to finance matters most for the entry of small firms and in sectors that are more dependent upon external finance. This finding is robust to controlling for other potential entry barriers (labor market regulations and entry regulations). On the other hand, financial development has either no effect or a negative effect on entry by large firms. Access to finance also helps new firms expand if successful. Both private credit and stock market capitalization are important for promoting entry and post entry growth of firms. Altogether, these results suggest that, despite significant progress over the past decade, many countries, including those in Continental Europe, should improve their financial markets so as to get the most out of creative destruction, by encouraging the entry of new (especially small) firms and the post-entry growth of successful young businesses.
\end{abstract}

JEL classification: D21, D92, L11, G32

Keywords: financial development, entry, post-entry growth, firm size, micro data

Harvard University; Paris-Jourdan Sciences Economiques; and OECD and IZA, respectively. We are grateful for helpful comments on a previous version of the paper to Aschish Arora, Thorsten Beck, Asli Demirguc-Kunt, Thomas Hellmann, Simon Johnson, Enrico Perotti, Paul Seabright and Scott Stern and as well as the participants to the NBER conference on "Entrepreneurship: Strategy and Structure" (Chicago, January 7, 2006); the World Bank conference on "Access to Finance" (Washington, March 15-16, 2007) and the University of Amsterdam conference on "Innovation and Early Stage Ideas" (Amsterdam, December 18-20, 2006). The views expressed in this paper are those of the authors and should not be held to represent those of the institutions of affiliation. The paper was prepared for the April 20-21 2007 Panel Meeting of Economic Policy in Frankfurt. 
There is growing empirical evidence suggesting that market economies are characterized by a continuous process of reallocation of resources and that this process play a major role for aggregate productivity and output growth (e.g. Olley and Pakes, 1996; Foster et al. 2002; Griliches and Regev, 1995; Bartelsman et al. 2004; and Aghion and Howitt, 2006). Resource reallocation is driven by incumbent firms adapting to market and technological changes, but also by firm dynamics - the entry of new firms, their expansion in the initial years of life and the exit of obsolete units. Firm dynamics is sizeable: several studies suggests that about 10 to 15 percent of all firms are either created or closed down every year in industrialized and emerging economies (see Caves, 1998; Bartelsman and Doms, 2000 and Ahn, 2000 for surveys). Many of the new firms that enter the market fail in the initial years of life, but those that survive tend to grow, often at a higher pace than incumbents firms (see e.g. Geroski, 1995; Sutton, 1997; Bartelsman et al. 2004).

While market forces and technological progress play a major role for firm dynamics, we do not fully understand what drives the differences in entry, post-entry and exit rates we observe across countries and over time. Previous studies have suggested a number of barriers to the entry and the post-entry growth, including: (a) adjustment costs induced by the R\&D and/or advertising of incumbent firms (e.g. Sutton, 1999; Geroski, 1995); (b) the administrative costs of creating a new firm (e.g. Djankov et al. 2002; Bertrand and Kramarz 2002; Desai et al. 2003; Scarpetta et al. 2002; Fisman and Sarria Allende, 2004); Klapper et al. 2006); and (c) labor market regulations (e.g. Micco and Pages, 2006; Haltiwanger et al. 2006). ${ }^{2}$

In this paper, we focus on credit constraints as a potential barrier to the entry and post entry growth of firms. First, we develop a stylized model in which sunk entry costs as well as post-entry growth potentials affect the entry decision and the post entry expansion of credit-constrained firms. This model allows us to also assess whether financial development has a differential effect on entry by firms of different size, where size affects firms' ability to borrow, and also to analyze the impact of financial development on the post-entry growth of firms. A main prediction of the model is that relaxing credit constraints has a more positive effect on the entry of small firms than of larger firms -- it may even discourage entry by the latter -- and that higher financial development increases post-entry growth of successful new firms. Second, we test these predictions empirically by using a harmonized firm-level panel data on entry and post entry growth of firms by sector, size classes and time in a sample of 16 OECD, transition, and Latin American countries over the 1990's. Contrary to most datasets used in the literature, our firm-level indicators are drawn from the entire population of firms

2 Djankov et al. (2002) used entry costs data from the World Bank (Doing Business Indicators) and showed that start-up costs are significantly higher in continental Europe than in the U.S. and generally higher in developing and most emerging economies than in industrialized countries. Desai, Gompers and Lerner (2003) use cross-country data to show that entry regulations have a negative effect on firm entry, while Bertrand and Kramarz (2002) look at the effect of the new zoning regulations in France on the expansion decisions of French retailers. Scarpetta et al (2002) use firm level data from 10 OECD countries to show that high product market and labor market regulations are negatively correlated with the entry of small and medium size enterprises. Fisman and Sarria Allende (2004) document that in countries with higher entry regulations, industries react to new growth opportunities by expanding existing firms instead of by creating new firms. Klapper et al. (2004) use the Amadeus database to show that entry regulations hamper entry in European countries, particularly in those sectors where entry should "naturally" occur. Finally, Micco and Pages (2006) and Haltiwanger et al. (2006) find evidence that stringent labor regulations, by raising labor adjustment costs, discourage the entry of firms especially in sectors characterized by relatively high job turnover. 
with at least 1 (or 10) employees and properly account for the entry (and exit) of firms. This dataset also allows considering entry rates by size classes and assessing post-entry growth of new firms over the initial years of their life. Consistently with our theoretical model, size is a crucial variable in the analysis of entry and post-entry growth: it accounts for the dominant fraction of the total variance in entry rates when compared with country or industry effects.

In the empirical analysis of entry and post-entry growth we consider different indicators of financial development. Given the difficulty of directly measuring its efficiency, most papers use indirect measures of size of financial intermediation and the structure of financial systems (Levine, 2005). We therefore consider the ratio of private credit and stock market capitalization to GDP. These are outcome variables and may be somewhat endogenous. However, we also instrument these variables using a detailed set of regulatory indicators that characterize the banking and securities markets. In the empirical analysis, we also use a difference-in-difference approach, following Rajan and Zingales (1998), to minimize problems of omitted variable bias and other miss-specifications. In particular, we interact different indicators of financial development with the relative dependence on external financing of the corresponding sector in the United States. The resulting difference in difference approach allows exploiting within-country differences between industry/sizes based on the interaction between country and industry characteristics.

Our main empirical results can be summarized as follows. First, we replicate earlier findings, namely that higher financial development enhances new firm entry in sectors that depend more heavily upon external finance. Second, we show that the entry of smallest size firms benefits the most from higher financial development, whereas the entry of largest firms is negatively correlated with credit. Third, we find robust evidence that financial development enhances post-entry growth of firms in sectors that depend more upon external finance. Our results are robust to using synthetic indicators of banks or financial market regulations to proxy for financial development and to also considering other policy variables, namely labor market regulation or entry costs.

This paper contributes to an extensive literature on finance, entry regulation, entrepreneurship, and growth. Here, we shall just mention the papers that are most closely related to our study. From a theoretical stand point, Lloyd-Ellis and Bernhardt (2000) assess the interplay between financial constraints and entrepreneurship in the context of a general equilibrium model with heterogeneous wealth endowments and heterogeneous investment costs. Albuquerque and Hopenhayn (2002) analyze lending and firm growth in a dynamic model where credit constraints arise from limited enforcement, whereas Clementi and Hopenhayn (2002) do the same using a model in which credit constraints arise from asymmetric information between lenders and borrowers.

On the empirical side, Evans and Jovanovic (1989) use data from the National Longitudinal Survey of Young Men to show that entrepreneurship, measured by the probability of entering self-employment and the volume of investments, is subject to binding liquidity constraints. Closer to our paper, Rajan and Zingales (1998) using industry-level data from the UNIDO show that financially-dependent industries tend to have better growth performance in more financially developed countries. Using similar data, Beck et al. (2005) show that financial development is more growth-enhancing for industries that rely more on small firms. Klapper, Laeven and Rajan (2005) use a data set of European firms to show that financial development has a positive effect on firm entry in sectors that are more dependent on external financing. They also suggest that strict entry regulations are associated with lower entry rates and larger 
entry size in sectors with higher natural turnover rates. Alfaro and Charlton (2006) use a large cross-sectional firm-level data set to show that reducing restrictions on international capital flows enhances firm entry. De Serres et al. (2006) find that regulation that is more conducive to competitive and efficient financial systems has a significant positive impact on sectoral output and productivity growth as well as on the entry of new firms in a sample of OECD countries. Finally, Perotti and Volpin (2004) use cross-country data from UNIDO to argue that democracy has a positive effect on net entry by increasing the degree of investment protection. However, these papers put little or no emphasis on firm size at entry or on post entry growth. They also tend to rely on country specific data or cross country data that do not allow computing entry rates but rather net entry rates (i.e. the net change in the number of businesses in a given industry, e.g. UNIDO data) or tend to exclude many small-sized businesses and/or cannot fully track the entry and exit of firms (e.g. most commercial databases providing accounting information).

The paper is organized as follows. Section 2 discusses the firm-level database used in the paper and provides a brief overview of the magnitude of entry and post entry growth across countries, industries and size categories. The section also presents the indicators of financial development used in the analysis. Section 3 presents our theoretical model and discusses its predictions which we then test in the empirical analysis. Section 4 presents the empirical results for the entry and post entry regressions. Section 5 draws some policy considerations from the empirical results, while Section 6 provides our concluding remarks and some policy considerations.

\section{Entry and post-entry growth: the data and some stylized facts}

The analysis developed in this paper is motivated by growing empirical evidence suggesting large firm dynamism (entry and exit of firms and post-entry growth) in all market economies and a significant role that this dynamism plays in promoting reallocation of resources and ultimately productivity growth. The evidence on the links between firm dynamics and productivity was originally concentrated in the U.S. but it has recently been extended to cover a wide range of OECD and increasingly developing and emerging economies. ${ }^{3}$ It suggests that, for example, net entry - the sum of the contribution of entry and that of exit of firms can account for about 20-25 percent of aggregate labor productivity growth in manufacturing in some EU countries, and for more than 30 percent in emerging economies. ${ }^{4}$ This direct contribution of entry and exit to productivity is also coupled by an indirect effect stemming from the market contestability effect, that is to say the strong pressure that firm entry and exit puts on incumbents to improve their own efficiency in order to maintain their market shares. There is also clear evidence that the contribution of new firms to overall productivity growth

3. See, among others, Geroski (1995); Caves (1998); Sutton (1997); Pakes and Ericson (1998); Ahn (2000); Bartelsman and Doms (2000); Davis and Haltiwanger (1999); Bartelsman, Haltiwanger and Scarpetta, (2004).

$4 \quad$ These results are drawn from productivity decompositions in which aggregate productivity growth is decomposed into different components, commonly called the 'within effect' (growth within each individual firm), 'between effect' (gains in productivity due to expanding market of high productivity firms), 'cross effect' (gains in productivity from high-productivity growth firms' expanding shares or from low-productivity growth firms' shrinking shares), 'entry effect' (gains in productivity due to high-productivity firms entering the market), and 'exit effect' (gains in productivity due to low productivity firms exiting the market). See Foster, Haltiwanger and Krizan (2001) and Bartelsman et al. (2004) for details on the decomposition for a sample of industrialized and emerging economies. 
tends to be larger in high-tech industries than in low-tech industries (Bartelsman et al. 2004); that is to say, where there are greater opportunities for technological adoption and products and process innovation entry plays a stronger role in driving aggregate productivity growth.

The significant cross-country and cross-industry differences in the intensity of firm dynamics and potential impact on productivity growth motivate our interest in financial development and other key institutional and policy factors. In this section, we review briefly some of the stylized facts on firm dynamics and highlight key differences across countries and sectors to guide us in our theoretical and empirical analyses.

\section{The firm-level indicators}

We assess the magnitude and key characteristics of firm dynamics drawing from a harmonized firm-level database that covers a sample of industrialized, developing and emerging economies. Given data availability on entry and post-entry growth we use a sample of 16 countries, namely Denmark, Finland, France, Germany, Italy, the Netherlands, Portugal, the United Kingdom and the United States, Hungary, Romania, Slovenia, Argentina, Chile, Colombia and Mexico (see Table 1). ${ }^{5}$

The key features of the micro-data underlying the analysis are as follows:

- Unit of observation: Data used in the study refer to the firm as the unit of reference, with the exception of Germany where data are only available with reference to establishments. More specifically, most of the data used conform to the following definition: "an organizational unit producing goods or services which benefits from a certain degree of autonomy in decision-making, especially for the allocation of its current resources" (Eurostat, 1998). ${ }^{6}$

- Size threshold: While some registers include even single-person businesses (firms without employees), others omit firms smaller than a certain size, usually in terms of the number of employees (businesses without employees), but sometimes in terms of other measures such as sales (as is the case in the data for France). Data used in this study exclude single-person businesses. However, because smaller firms tend to have more volatile firm dynamics, remaining differences in the threshold across different country datasets should be taken into account in the international comparison.

5. The original sample includes 24 countries. However, for the three East Asian countries - South Korea, Taiwan (China) and Indonesia - data are draw from business censuses and are available only every 3-5 years. This does not allow estimating annual entry rates or post-entry growth. For Brazil and Venezuela, the coverage of small firms is limited in the available data, somewhat limiting their relevance for the purpose of this paper. For Canada the data is not detailed by size classes. For Latvia and Estonia, the number of firms in the economy is too small, which limits the ability to compute consistent entry rates for a large number of sectors. Moreover, for these countries we do not have long time series (less than 6 years). We checked whether these choices affected entry regressions: a sensitivity analysis was conducted including Brazil, Venezuela, Latvia and Estonia and the results for entry rates by size classes are similar. Details are available from the authors.

6 It should be stressed that only in some of the countries in the sample organizational changes, such as mergers and acquisitions are fully taken into account. We control for these possible differences across countries by including in our empirical analysis a full set of dummy variables controlling for country/ size effects. 
- Industry coverage: National data have been organized along a common industry classification (ISIC Rev. 3). In the panel datasets, firms were allocated to the single ISIC industry that most closely fit their operations over the complete time-span for which the firm is observed. ${ }^{7}$

The firm-level data come from business registers (Denmark, Finland, the Netherlands, the United Kingdom and the United States, Slovenia and Romania), social security databases (France, Germany, Italy, Mexico) or corporate tax rolls (Argentina, France, Hungary), as shown in Table 1. Annual industry surveys are generally not the best source for firm demographics, due to sampling and reporting issues, but have been used nonetheless for Chile, and Colombia. Data for Portugal are drawn from an employment-based register containing information on both establishments and firms. All these databases allow firms to be tracked over time because addition or removal of firms from the registers reflects the actual entry and exit of firms. We define five size classes based on the number of firm employees: 119 workers, 20-49 workers, 50-99 workers, 100-499, and 500 or more workers.

\section{TABLE 1 HERE}

\section{Firm dynamics and productivity growth}

\section{Fact 1: Sizeable firm turnover in all countries}

Our data confirm a high firm churning in all countries in the sample. In Figure 1 we present entry and exit rates for the total business sector and manufacturing focusing on firms with at least 20 to maximize the country coverage. ${ }^{8}$ Total firm turnover (entry plus exit rates) involves 3-10 per cent of all firms in most industrial countries and more than 10 per cent in some of the transition economies for which we have the data. ${ }^{9}$ If we also extend the analysis to include micro units (1 to 19 employees), we find that between one-fifth and one-fourth of all firms are either created or closed-down every year in our sample of countries. There is also a high correlation of industry-level entry rates with exit rate in most countries, suggesting that firm turnover not only account for the life cycle of different industries - some in the early phases of the life cycle and expanding, other in more mature phases that consolidate - but also

$7 \quad$ Following the approach used in Klapper et al. (2006), we excluded some industries from the analysis, namely: agriculture and mining, manufacturing n.e.c., electricity, gas and water supply, financial intermediation, and community, social and personal services.

8 The entry rate is defined as the number of new firms divided by the total number of incumbent and entrants firms producing in a given year; the exit rate is defined as the number of firms exiting the market in a given year divided by the population of origin, i.e. the incumbents in the previous year.

9 Cross-country comparisons of firm turnover may be affected by differences in the industry composition of the different countries. Bartelsman et al. (2004) decompose the effects of sectoral composition and within sector differences in firm turnover and find that the variability of turnover rates for the same industry across countries is comparable in magnitude to that across industry in each country. The importance of industry effects that hold across countries supports our empirical analysis that exploits cross-industry variation in the sample of countries to assess the role of financial constraints and other regulations. 
for a continuous process of reallocation of resources in which new businesses displace obsolete units (a point also highlighted by Audretsch, 1995). ${ }^{10}$

\section{FIGURE 1 HERE}

\section{Fact 2: Firm turnover is largely driven by small- and medium-sized businesses}

Size is a crucial dimension in the analysis of firm entry and exit. Not surprisingly, small firms (fewer than 20 employees) account for more than 80 percent of total firm turnover and firm turnover tend to decline with size. However, this is not completely true for some European countries where entry and exit rates tend to decline less steeply as one moves from small to larger size classes. This suggests a possible role of the business environment that reduces firm dynamics among medium-sized businesses.

In Table 2 we quantify the role that the different dimensions of the data - size, industry and country -- play in explaining the overall variance in entry rates. The analysis of variance is performed for the unbalanced total economy and the manufacturing sector. ${ }^{11}$ It is noticeable that technological and market structure characteristics that are reflected in industry-specific effects explain only 3.3 per cent of the overall variations in entry rates. Country-specific factors explain more of the variation in entry rates than the industry factors, but the dominant role is indeed played by the size dimension that alone accounts for about one-third of the total variance, while the combined industry* size effects account for more than 40 percent. These results clearly indicate the importance of exploiting the size dimension in the analysis of firm turnover data. Previous studies that did not differentiate entry rates (or firm turnover) by size are likely to have missed an important source of cross-country variation and one that is likely to be directly driven by the institutional and policy framework in which firms operate.

\section{TABLE 2 HERE}

\section{Fact 3: Market selection is harsh and many new firms exit quickly}

Figure 2 presents non-parametric estimates of survivor rates for firms that entered the market in the late 1980s and 1990s in the manufacturing sector of our sample of countries. The survivor rate specifies the proportion of firms from a cohort of entrants that still exist at a given age. ${ }^{12}$ The Figure suggests that market selection is harsh in all countries. The initial years are particularly tough: about 10 to 30 percent of entering firms do not pass the market test and are forced out within the first two years of life. Conditional on overcoming the initial years, the survival prospect of firms improves: firms that remain in business after the first two

10 In the transition economies, the weaker correlation of entry and exit rates across industries is largely due to the systemic changes in which some over-populated industries shrank while others - including most business-sectors - expanded.

11 The total economy sample is unbalanced because it only covers manufacturing industries for the United Kingdom, Chile and Colombia

12 In the figure, the survival rates are averaged over different entry cohorts and do not take into account differences in the industry composition across countries. Bartelsman et al. (2004) also look at the role of sectoral composition. Notably we find that the variation across countries is more systematic than that across industries. Across industries, after four years between 60 and 80 percent of firms survive, while for example the survival rate in office and computing equipment deviates from 40 percent below to 40 percent above the cross-country average of 70 percent. 
years have a 40 to 80 per cent chance of surviving for five more years. ${ }^{13}$ Nevertheless, only about 30-50 percent of total entering firms in a given year survive beyond the seventh year in most countries. ${ }^{14}$ Moreover, for most countries, the rank ordering of survival is similar whether using a 2-year, 4-year or 7-year horizon suggesting that there is an important country effect that impacts the survival function. ${ }^{15}$

\section{FIGURE 2 HERE}

\section{Fact 4: Post-entry growth of successful new businesses varies a lot across countries}

If market selection is hard, growth potentials for successful entrants can be great, but strongly depend on the business environment in which firms operate. To assess cross country differences in post-entry growth, Figure 3 shows the average size of surviving firms at different ages compared with that at entry. It clearly shows significant cross-country variations: for example, successful new firms tend to expand more rapidly in the U.S. than in Europe. This is partially due to the larger gap between the size at entry and the average firm size of incumbents, i.e. there is a greater scope for expansion amongst young ventures in the US markets than in Europe. It can also reflect better business environment conditions that allow new firms to enter relatively small and, if successful, expand rapidly to approach the minimum efficient scale. This finding suggests that the analysis of firm dynamics and its links with financial development and other institutional factors cannot only focus on entry, but should also explore the development of new ventures in the first years of their life.

\section{FIGURE 3 HERE}

There are two main facts that clearly emerge from our brief review of firm dynamics in our sample of industrialized and emerging economies and that have guided our theoretical and empirical analyzes. First, while sizeable every where, firm entry rates vary across countries and, especially across size classes within each country. This confirms the importance of assessing the possible influence that financial development and other business environment conditions exert on them. Second, it clearly indicates large variations in the post entry behavior of firms, which can again be influenced by access to credits of new small businesses as well as by regulatory conditions.

\section{A simple model}

\section{Basic setup}

13 These results are consistent with a number of other studies, including (see Evans 1987a, 1987b; Dunne et al. 1988, 1989).

14 Survival rates presented in the Figure are higher in transition economies. New firms in these countries populated new areas of business activity (especially in the service sector) and - at least in the initial years of the transition period - were less exposed than their counterparts in industrialized and emerging economies to strong competition from either insiders or other outsiders.

15 However, there are a few interesting exceptions. The U.S. has relatively low survival rates at the 2year horizon but relatively higher survival rates at the 7-year horizon. This pattern might reflect the relatively rapid cleansing of poorly performing firms in the U.S. 
How can we formalize the links between financial development - and other business regulations - and entry and post entry growth? To address this question, we present in this section a simple model which draws from Aghion et al. (2006). Consider an economy populated by a continuum of overlapping generations of two-period lived individuals. There are two types of individuals in the economy, the entrepreneurs and the investors. Entrepreneurs differ in their initial production capacity $\theta_{0}$ (their size at birth time $t$ ) and in their potential capacity in the long term $\theta_{1}$ (their size at time $t+1$ ). Thus, new entrants at time $t$ produce in periods $t$ and $t+1$, and exit the market before time $\mathrm{t}+2$. Initial capacity $\theta_{0}$ is uniformly distributed between 0 and $\bar{\theta}_{0}$, whereas $\theta_{1}$ is uniformly distributed between 0 and $\bar{\theta}_{1} \cdot 16$

Entrepreneurs can borrow from a large number of investors. We assume that lenders can assess the entrepreneurs' initial production $\theta_{0}$, which is observable, but not their long-term capacity $\theta_{1}$.

There are two goods in the economy: a numeraire good which serves as production and entry input, and a consumption good.

The life cycle of an entrepreneur born at time $t$ can be described as follows.

\section{At time $t$ (short term):}

- New entrepreneurs decide whether or not to enter the sector that produces the consumption good. The entry involves a sunk cost $b$ in units of the numeraire good. If they do not enter, their profit is 0 .

- Entrepreneurs who enter the consumption good market produce and sell at the equilibrium price that clears the consumption good market at time $t$. For simplicity we normalize production costs at zero. ${ }^{17}$

- Entrepreneurs may then decide to expand capacity for period $t+1$. By investing $I$ units of numeraire good, they can expand their long-term capacity from $\theta_{1}$ to $(1+\alpha I) \theta_{1}$.

\section{At time $t+1$ (long term):}

- Entrepreneurs produce and sell at the equilibrium price that clears the consumption good market at that time. We shall focus attention to the stationary equilibrium in which the equilibrium price $p$ is the same in all periods, and analyze how a change in financial development affects this stationary equilibrium.

Let $D(p)$ denote the aggregate demand for the consumption good at any period. Total supply of the consumption good at time $t+1$ is equal to the sum of the long-term aggregate

16 We do not need to assume that $\left(\theta_{0}, \theta_{1}\right)$ are independently distributed. For example, our results carry through if $\theta_{1}=(1-\eta) \theta_{0}+\eta \varepsilon$ and $\varepsilon$ is independent from $\theta_{0}$.

17 Moving to the more realistic case with positive labor cost, only involves replacing $p$ by $p=p$ - $w$ instead of $p$ in the following analysis. Since $w$ is exogenous, the general case leads to the same conclusions. 
production capacity of entrants from time $t$ and of the short-term production capacity of new entrants at time $t+1$.

\section{Credit constraints}

Let's us assume that only short term production $\theta_{0}$ can be used as collateral. Moreover, consider an entrepreneur who wants to invest $k$ units of numeraire at entry and borrows that amount from the capital market at time $t=0$. Ex post, the entrepreneur can choose either to repay $k$ or to stall at a cost $\tau k$ proportional to the amount invested and lose the value of its collateral $p \theta_{0}$. Thus, ex post enforcement requires that:

$$
k<\tau k+p \theta_{0}
$$

or

$$
k<\mu p \theta_{0}
$$

where the credit multiplier $\mu=1 /(1-\tau)$ reflects the level of financial development. In particular, entrepreneurs with initial capacity $\theta_{0}$ can enter only if:

$$
b<\mu p \theta_{0}
$$

where $b$ denotes the entry cost. Then, the maximum amount an entrepreneur may invest in long-term capacity expansion is $\mu p \theta_{0}-b$.

\section{Solving the model}

For the sake of exposition, we first rule out the possibility of ex post capacity expansion: that is to say, we assume $\alpha=0$.

Entrepreneurs with initial capacity $\theta_{0}<b / \mu p$ cannot raise enough cash to pay the entry fee, and therefore will not enter the consumption good market no matter their long term capacity $\theta_{1}$. Note that the cut-off level:

$$
\theta_{0}^{*}=\frac{b}{\mu p}
$$

is lower the higher the level of financial development $\mu$ and the higher the equilibrium price $p$ on the consumption goods market.

Next, consider an entrepreneur with initial capacity $\theta_{0}>\theta_{0}^{*}=b / \mu p$. If she enters, she will make profits in all periods and will not exit. Her net present value upon entry is then equal to:

$$
\Pi=p \theta_{0}+\delta p \theta_{1}-b
$$

where $\delta$ is the discount factor. 
Normalizing at zero the payoff of an entrepreneur that does not enter the consumption good market, an entrepreneur with initial capacity $\theta_{0}>\theta_{0}^{*}=b / \mu p$ will enter whenever $\Pi>0$ or equivalently:

$$
\theta_{0}+\delta \theta_{1}>\frac{b}{p}
$$

In particular, given $\theta_{0}$, the minimal long-term capacity threshold is:

$$
\theta_{1}^{*}=\frac{b}{\delta p}-\frac{\theta_{0}}{\delta}
$$

We can now solve for the equilibrium consumption good price in a stationary equilibrium. As we focus on stationary equilibrium, we drop time subscripts. The aggregate supply of consumption good is a decreasing function of both capacity thresholds $b / \mu p$ and $b / p$. Thus, it is increasing in $\mu, \mu p$ and $p$. Let $S(\mu p, p)$ denote the aggregate supply, increasing in both arguments. Since aggregate demand $D(p)$ for the consumption good is a decreasing function of its price and supply is increasing with price, the equilibrium is uniquely determined by:

$$
D(p)=S(\mu p, p)
$$

Moreover, since aggregate supply $S$ is increasing with the level of financial development $\mu$, the equilibrium price $p$ is decreasing with $\mu$.

Finally, since the equilibrium price $p$ is decreasing with $\mu$, we obtain that $\mu p$ is increasing with $\mu$ (the appendix provides a formal proof).

It then immediately follows from this discussion that an increase of financial development $\mu$ induces: (i) a decrease of the cut-off entry $\operatorname{size} \theta_{0}^{*}$, which means that smaller firms can enter; (ii) a decrease in the equilibrium price $p$, and therefore an increase in the capacity thresholds $\theta_{1}^{*}$, which in turn means that fewer large firms with $\theta_{0}>\theta_{0}^{*}$ will enter; (iii) an increase in post-entry growth, because size at entry decreases and long-term size increase (see figure 4 for a graphical illustration).

What happens when we allow for capacity expansion? In fact, one can show that the analysis will remain qualitatively the same as before concerning entry decisions, with the same threshold $\theta_{1}^{*}$, as long as $\alpha b<1$, where $\alpha$ is the rate of return to capacity growth, except that now the long-term capacity expansion $\mu p \theta_{0}-b$ also increases. To see this, note that the optimal expansion investment $I$ solves

$$
\begin{aligned}
& \max _{I}\left\{p \theta_{0}+\delta p \theta_{1}(1+\alpha I)-b-I\right\} \\
& \text { s.t. } \quad I \leq \mu p \theta_{0}-b
\end{aligned}
$$


In particular firms will expand (i.e $I>0$ ), whenever

$$
\delta p \theta_{1} \alpha>1
$$

When $\alpha b<1$, this condition is more stringent than the condition

$$
\theta_{1}>\theta_{1}^{*}
$$

for profitable entry, which means that there will be a range of firms with $\theta_{1}>\theta_{1}^{*}$ which enter but do not expand. A higher $\mu$ will increase post entry growth for those firms that decide to expand, which in turn will contribute to increasing aggregate supply thereby reducing the equilibrium price for the consumption good.

\section{Summarizing the main predictions}

The model predicts that an increased level of financial development: (i) will foster entry by small firms but discourage entry by those larger firms that do not have the best long term prospects; (ii) will foster post entry growth of all entering firms. In the next section we shall confront these predictions to the data.

\section{Measurement and estimation method}

\section{The econometric strategy}

We test the predictions of our stylized model by exploiting the observed industry/size and time variations in the harmonized firm-level database through a difference-in-difference approach (see Rajan and Zingales, 1998) ${ }^{18}$. The difference-in-difference approach consists in identifying an industry-specific factor that affects the way financial development -- or other business regulations -- impact on the decision of firms to enter the market or expand their activities in the early years of life.

We assume that industries that depend more heavily on external financing would be more affected by a weak financial market. In particular, we use the relative dependence of external financing observed in the U.S. industries as the interacting factor for the different indicators of financial development. Since the desired amount of external financing in each industry is not observed, we can proxy it by using the actual amount of funds raised externally when financial markets are sufficiently developed so as to provide firms with un-constrained access to external financing. Following Rajan and Zingales (1998), we assume that the U.S. financial markets come closest to provide such access and, accordingly, take US listed firms to define the industry-specific need of external finance. Therefore, we assess whether industries that depend more heavily on external financing are disproportionately affected by weak financial market conditions.

18 The difference-in-difference approach has already been used in a number of empirical studies in the corporate literature (e.g., Classens and Laeven, 2003), as well as in the analysis of firm entry (Klapper et al. 2004) and in the analysis of job flows (Haltiwanger et al. (2006). We specially thank Klapper, Laeven and Rajan for providing us with the index of dependence in external finance in NACE code. 
In the augmented model, in which we also consider other policy and regulatory variables, we interact each of them with a salient industry characteristics, namely labor intensity (or gross job flows) for labor regulations and total firm turnover (or the relative value added growth) for entry regulations.

The advantage of the difference-in-difference approach compared to standard crosscountry/cross-industry studies is that it allows exploiting within country differences between industry cells based on the interaction between country and industry characteristics. Thus, we can also control for country and industry effects, thereby minimizing problems of omitted variable bias and other misspecifications.

\section{Estimated entry equations}

Following our stylized model, we run a set of specifications for the entry and the post-entry equations. Our data have four dimensions: (c) country; (i) industry -- 2-digit manufacturing and business services; (s) size; and (t) time. In all our specifications, we control for country-size effects and industry-size effects due to other market, technological or regulatory factors not included in the regressions. Size specific country dummies also control for differences in sample thresholds. The measure of entry rate used in the empirical analysis is the ratio of the total number of firms that entered the market in a given industry, size class and year over the total number of firms in that industry and size class. To control for size effects -within each size class -- we also weight entry rate by employment.

We first regress entry rates on our indicators of financial development, measured in different ways, interacted with the indicator of dependence on external financing (ExtDep). We can write the equations as follows:

$$
\begin{aligned}
\text { Entry }_{\mathrm{c}, \mathrm{i}, \mathrm{s}, \mathrm{t}} & =\delta\left(\text { FinDev }_{\mathrm{c}} * \text { ExtFin }_{\mathrm{i}}\right) \\
& +\sum_{c=1}^{C} \sum_{s=1}^{S} \beta_{\mathrm{c}, \mathrm{s}} D_{\mathrm{c}, \mathrm{s}}+\sum_{i=1}^{I} \sum_{s=1}^{S} \gamma_{\mathrm{i}, \mathrm{s}} D_{\mathrm{i}, \mathrm{s}} \\
& +\sum_{t=1}^{T} \theta_{\mathrm{t}} D_{\mathrm{t}}+\varepsilon_{\mathrm{c}, \mathrm{i}, \mathrm{s}, \mathrm{t}}
\end{aligned}
$$

In these specifications we examine whether the difference in industry-size entry rates between industries with high or low dependence on external financing is smaller in countries with better financial markets. Thus, by including the interactions between our variable on financial development and the industry-specific characteristic, we can control for unobserved countrysize and industry-size fixed effects.

We then allow for the coefficients of the interactions of our variable on financial development and the dependence in external finance to vary by firm size groups. Formally, we estimate the equation: 


$$
\begin{aligned}
\text { Entry }_{\mathrm{c}, \mathrm{i}, \mathrm{s}, \mathrm{t}} & =\sum_{s=1}^{S} \delta_{\mathrm{s}}\left(\text { FinDev }_{\mathrm{c}} * \operatorname{ExtFin}_{\mathrm{i}}\right) \\
& +\sum_{c=1}^{C} \sum_{s=1}^{S} \beta_{\mathrm{c}, \mathrm{s}} D_{\mathrm{c}, \mathrm{s}}+\sum_{i=1}^{I} \sum_{s=1}^{S} \gamma_{\mathrm{i}, \mathrm{s}} D_{\mathrm{i}, \mathrm{s}} \\
& +\sum_{t=1}^{T} \theta_{\mathrm{t}} D_{\mathrm{t}}+\varepsilon_{\mathrm{c}, \mathrm{i}, \mathrm{s}, \mathrm{t}}
\end{aligned}
$$

Last, we control for alternative policy variables interacted with a specific industry factor. We consider labor regulations, interacted with an index of job reallocation in US (Jobflows $U$, gross job flows among US incumbents in the same sector) ${ }^{19}$, and start-up regulations, interacter with the natural firm turnover (Turnover $_{U S}$, measured as average exit and entry rates in US sectors) or the relative growth of value added in the US (Rdlva $a_{U S}$ ). Labeling the institutional or regulatory variable as "policy" and the industry-specific factor as "industry factor”, this multivariate specification can be written as follows:

$$
\begin{aligned}
\text { Entry }_{\mathrm{c}, \mathrm{i}, \mathrm{s}, \mathrm{t}} & =\sum_{s=1}^{S} \delta_{\mathrm{s}}\left(\text { FinDev }_{\mathrm{c}} * \text { ExtFin }_{\mathrm{i}}\right)+\sum_{s=1}^{S} \chi_{\mathrm{s}}\left(\text { Policy }_{\mathrm{c}} * \text { Industryfactor }_{\mathrm{i},}\right) \\
& +\sum_{c=1}^{C} \sum_{s=1}^{S} \beta_{\mathrm{c}, \mathrm{s}} D_{\mathrm{c}, \mathrm{s}}+\sum_{i=1}^{I} \sum_{s=1}^{S} \gamma_{\mathrm{i}, \mathrm{s}} D_{\mathrm{i}, \mathrm{s}} \\
& +\sum_{t=1}^{T} \theta_{\mathrm{t}} D_{\mathrm{t}}+\varepsilon_{\mathrm{c}, \mathrm{i}, \mathrm{s}, \mathrm{t}}
\end{aligned}
$$

\section{Post-entry growth equations}

Post-entry growth data are available at different time in the life of each new cohort of entrant firms. We focus our empirical analysis on the sixth year of life of the new firms. This allows capturing the effects of learning by doing by new firms in the initial years of activity, as well as market selection. Our post-entry growth variables are: i) the post-entry change in employment of surviving firms after six years of activity; and ii) the total change in the employment of a cohort after six years. While the former explores the post-entry performance of successful firms, the latter includes both the changes in employment of successful firms and the job losses of new firms that exit the market in the first six years of activity (we will focus on the first measure and analyze the total employment growth in the last section). Moreover, we take averages of post-entry growth and total employment changes of different cohorts over the period covered by the data. In other words, our indicators vary by country and industry level. Formally, our post-entry growth equation can be specified as follows:

$$
\begin{aligned}
P E G_{\mathrm{c}, \mathrm{i}}= & \delta\left(\text { FinDev }_{\mathrm{c}} * \operatorname{ExtFin}_{\mathrm{i}}\right) \\
& +\sum_{c=1}^{C} \beta_{\mathrm{c}} D_{\mathrm{c}}+\sum_{i=1}^{I} \gamma_{\mathrm{i}} D_{\mathrm{i}}+\varepsilon_{\mathrm{c}, \mathrm{i}}
\end{aligned}
$$


A multivariate specification, controlling for labor regulation (interacted with the index of gross job flows in US), may be rewritten:

$$
\begin{aligned}
\operatorname{PEG}_{\mathrm{c}, \mathrm{i}}= & \delta\left(\text { FinDev }_{\mathrm{c}} * \text { ExtFin }_{\mathrm{i}}\right)+\chi\left(\text { policy }_{\mathrm{c}} * \text { industryfactor }_{\mathrm{i}}\right) \\
& +\sum_{c=1}^{C} \beta_{\mathrm{c}} D_{\mathrm{c}}+\sum_{i=1}^{I} \gamma_{\mathrm{i}} D_{\mathrm{i}}+\varepsilon_{\mathrm{c}, \mathrm{i}}
\end{aligned}
$$

Since post-entry growth may simply depend on the size at entry, as shown in the first part of the model without investment in capacity expansion, we also examine a specification controlling for the average size of cohorts:

$$
\begin{aligned}
\text { PEG }_{\mathrm{c}, \mathrm{i}}= & \delta\left(\text { FinDev }_{\mathrm{c}} * \text { ExtFin }_{\mathrm{i}}\right)+\sigma_{0} \text { size of entrants }_{c, i} \\
& +\sum_{c=1}^{C} \beta_{\mathrm{c}} D_{\mathrm{c}}+\sum_{i=1}^{I} \gamma_{\mathrm{i}} D_{\mathrm{i}}+\varepsilon_{\mathrm{c}, \mathrm{i}}
\end{aligned}
$$

Last, in order to show that financial development particularly affects entrants and that postentry growth is not simply related to the growth of incumbents, we consider the following specification:

$$
\begin{aligned}
P_{\mathrm{C}, \mathrm{i}}= & \delta\left(\text { FinDev }_{\mathrm{c}} * \text { ExtFin }_{\mathrm{i}}\right)+\sigma_{1} \text { growth of all firms }_{c, \mathrm{i}} \\
& +\sum_{c=1}^{C} \beta_{\mathrm{c}} D_{\mathrm{c}}+\sum_{i=1}^{I} \gamma_{\mathrm{i}} D_{\mathrm{i}}+\varepsilon_{\mathrm{c}, \mathrm{i}}
\end{aligned}
$$

Alternative specifications will be examined in the robustness section.

\section{The indicators of financial development and other regulations}

In the empirical analysis we use two traditional (outcome) indicators of the degree of financial development, but also consider a set of regulatory variables that affect them. The outcome indicators are: i) the ratio of domestic credit to the private sector to GDP (from the IMF International Financial Statistics); and ii) the ratio of stock market capitalization to GDP (from Standard and Poor's and World Bank's World Development Indicators). ${ }^{20}$ We also consider a synthetic indicator of financial development defined as the sum of the private credit and market capitalization ratios.

The regulatory indicators of banking and securities markets are drawn from difference sources. ${ }^{21}$ For banking, we focus on regulations that affect competition and we do not consider regulations that primarily aim at financial stability with more limited adverse effects on competitive pressure. We use four main indices:

- The share of government assets over total banking assets. In order to have time series that refer to the period under analysis, we use the index from Micco, Panizza and

20 See Beck, Levine and Demirgurc-Kunt (2000).

21 We have followed here the approach proposed by de Serres et al. (2006). 
Yañez (2004) applying the same method as La Porta, Lopez-de-Silanes and Shleifer $(2002){ }^{22}$

- Entry requirements in banking, which measures barriers to the entry of domestic firms. The data comes from "Bank, Regulation and Supervision Database" (see Barth, Caprio and Levine, 2003). The index gathers information about licensing requirements for setting up a bank in each country. ${ }^{23}$

- Barriers to foreign entry. The index is taken from the "Economic Freedom of the World (EFW)" database (see Gwartney and Lawson, 2004). It draws itself from different sources: the World Economic Forum (2001); the Global Competitiveness Report, 2001-2002; and the Bank, Regulation and Supervision Database (see Barth, Caprio and Levine, 2003). It considers both the rate of denial of foreign bank license and the share of foreign bank assets in total bank assets.

- Regulation of bank activity. This index is constructed using the Bank, Regulation and Supervision Database (Barth, Caprio and Levine, 2003) and measures the regulatory restrictiveness for bank participation in securities activity, insurance, real estate and ownership of non-financial firms.

Figure 5 shows these regulatory indicators for our sample of countries. It shows significant variation across countries with some smaller European countries and the UK and US. generally having lower government direct intervention and easier entry conditions than than in many emerging economies and larger Continental EU countries.

For securities markets, we consider indices taken from the World Bank Doing Business (2006) database and Djankov, McLiesh and Shleifer (2006) (see Figure 6). In particular:

- Investor protection. Captures the strength of minority shareholder protection against directors' misuse of corporate asset for personal gain from three perspectives: transparency of transactions, liability for self-dealing and shareholders' ability to sue directors for misconduct. As emphasized by Perotti and Volpin (2004) and others, the level of investor protection is a key indicator of financial development. This index is taken from the "Doing Business" database.

- Creditor rights. This index is from the "Doing Business" database and measures the degree to which collateral and bankruptcy laws facilitate lending.

- Information sharing. This index measures the presence of public or private registries. Djankov, McLiesh and Shleifer (2006), using time series over a long time period, have shown that that the presence of public or private registry coverage induces more

22 La Porta, Lopez-de-Silanes and Shleifer (2002) show that government ownership of banks has a negative impact on financial development and growth. For 2002, both indices are correlated at more than $85 \%$ for all countries or just the country which are covered by our analysis. Moreover, our results are robust to using La Porta, Lopez-de-Silanes and Shleifer (2002) index. 
developed credit markets. Since asymmetric information is a main source of financial constraints, information sharing is therefore likely to boost financial development.

- Contract enforcement. The index is drawn from Djankov, McLiesh and Shleifer (2006) who show that the time to enforce a debt contract (in log) has a negative and significant impact on financial development.

- Average time to complete bankruptcy procedures (in log). It measures the efficiency of bankruptcy laws and its proceedings with respect to the time required to go through the bankruptcy procedure. This index is from the "Doing Business" database.

Figure 6 reports these indicators for our sample of countries. Again, it shows wide disparities across countries.

We first use a two-stage approach, regressing financial development (either private credit or stock market capitalization) on the corresponding set of policy variables and then taking the fitted value in the entry and post-entry growth regressions. Because of the small number of countries and the potential correlation between our policy variables, we also consider the simple average of our indices as a robustness test. In order to put all indices on an equal footing, we rescaled them from zero to one, one being the "best performing" country. The sensitivity analysis confirms that the use of simple averages of the regulatory indicators instead of the fitted values from the financial development regressions does not affect significantly our estimated results.

Entry and post entry decisions are also influenced by a host of other factors. In our empirical analysis, we consider two key regulatory aspects: regulations affecting start-up costs; and regulations affecting the hiring and firing workers. The former, if enforced, are likely to discourage the entry of firms, especially those of small size for which the start up costs may account for a significant share of the overall project costs. Likewise, employment protection legislation, by raising labor adjustment costs, is likely to affect the decision to enter the market, but also the optimal strategy of size at entry and post entry expansion once the response of the market in known. In this paper we consider two indicators from "Economic Freedom of the World (EFW)" summarizing the stringency of regulations affecting start ups and labor adjustment. In particular:

- Regulations affecting start-up costs. The indicator considers the cost and procedural inconveniences to set up a new business. The original indicator from EFW was rescaled from 0 to 1 with 1 being the most restrictive.

- Employment protection legislation. We use a synthetic indicator of hiring and firing restrictions rescaled from 0 to 1 , with 1 being the most restrictive. ${ }^{24}$

The main advantage of the EFW regulatory indicators compared to others available in the literature is their time dimension and country coverage. Indeed, other indicators are either available for all countries but at one point in time only (e.g., indicators from the World Bank

24 This synthetic indicator of EPL is highly correlated with another indicator available only for the OECD countries and that arguably offers a more comprehensive coverage of regulatory aspects affecting the hiring and firing process (see OECD, Employment Outlook, 2003). The correlation between the two indicators for the OECD sample is 0.85 , statistically significant at the 1 percent level. 
Doing Business database that are available only for the 2000s), ${ }^{25}$ or available over time but only for a subset of the countries covered in our study (e.g. the OECD regulatory indicators). Since most of the countries included in our analysis have experienced significant regulatory reforms since the period covered by our entry and post-entry growth data, the time dimension of the EFW was of primary importance. It should also be stressed that the cross-country correlations of the EFW indicators with others available in the literature is generally very high (see Table 3 for details on the regulatory variables).

\section{TABLE 3 HERE}

\section{Empirical results}

\section{Average impact on entry}

We look first at the average impact of financial development without differentiating by size, as it has been done in previous empirical studies. Table 4 presents our results. In column (1) we interact the index on financial development with the index of external financial dependence. The coefficient is estimated using all size categories. It is positive and significant, suggesting that entry rates are, ceteris paribus, larger in industries with greater dependence on external financing in countries with more developed financial markets. Note that $F D$ is an index of financial development that takes both private credit and stock market capitalization into account. In columns (2) and (3) we consider each component in turn. The coefficients are significant and positive for both indices. These results are similar to Klapper, Leaven and Rajan (2006), who also find a positive and significant impact of financial development (private credit interacted with the dependence in external finance) on entry rates. It is also coherent with previous studies finding a positive impact on net entry rates (including Rajan and Zingales 1998).

\section{TABLE 4 HERE}

How sizeable is the estimated impact of financial development on entry rates? Given our estimation approach, we consider the effect of financial development in reducing entry rates between two industries at the extremes of the distribution of industry by the degree of dependence on external financing. Using the coefficient of the interaction terms, we estimate the difference in entry rates between industries with a high dependence on external financing $\left(90^{\text {th }}\right.$ percentile of distribution in the United States) and industries with a low dependence $\left(10^{\text {th }}\right.$ percentile of the same distribution) in a country with the highest index of financial development compared to the country with the lowest index, as follows:

$$
\beta\left[\left(E x t D e p_{90 t h}-E x t D e p_{10 t h}\right)\left(F D_{\max }-F D_{\min }\right)\right]
$$

where $\beta$ is the estimated coefficient, ExtDep and FD are the dependence on external financing and the indicator of financial development, respectively. From our result from column (1), the impact of financial development on entry rates (weighted by employment) is then 1.3 percentage points - i.e. 26 percent of the observed sample mean. If we consider private credit and stock market capitalization separately, we estimate an impact of 1.4 and 1.1 respectively. 
This average effect of financial development on entry across size categories may not look particularly strong. However, as we shall see in the next subsection, the effect becomes much larger once we differentiate firm entry rates by size.

\section{Effects on entry by size categories}

As stressed in Section 2, entry rates vary significantly across firm size within each country, and the predictions of our model is that regulations and financial development may impact very differently entrants with different size. In particular, according to prediction (1) and (2) of the model, we expect a positive impact of financial development on entry of small firms and a negative impact on the entry of large firms. To test for these predictions, we relax the hypothesis of common coefficient of the interactions and allow them to vary by size classes. As in the previous case, we allow for country-size and industry-size fixed effects. In other words, all parameters are size specific.

\section{TABLE 5 HERE}

In column (1) of Table 5, the coefficient for the interaction between financial development and external dependence is positive and significant for very small ( 1 to 19 employees) and small (20 to 49 employees) firms and becomes even negative for larger firms (100 to 499 employees or more than 500 employees). In other words, financial development boosts entry among small firms in sectors depending more on external finance but may even curb entry among very large firms. As we can see in columns (2) and (3), these effects are robust across different measures of financial development, namely private credit and stock market capitalization. Interacted with external financial dependence, the impact on small firms is large and positive for both and becomes negative for larger firms. The positive effect on small firms and the negative effect on large firms seem slightly stronger for private credit.

These results are based on outcome variables of financial development. Since our primary interest is the potential impact of policies, we need to assess the robustness of these results using regulatory factors that affect the estimated overall degree of development of financial markets.. In column (4), we instrument private credit with regulatory variables that are likely to have an impact on the banking system. As we mentioned in section 3, we consider four main policy variables for banking regulation: the share of assets owned by the government over total bank assets, barriers to the entry of foreign banks, entry requirements and the regulation of banking activity. The results are very similar. In column (5), we instrument stock market capitalization by contract enforcement, creditor rights, public or private registries, investor protection and bankruptcy procedures. We obtain coefficients that are even larger than without instrumentation, being higher for small firms and more negative for large firms. In columns (6) and (7), we directly regress entry rates on these regulatory and policy variables. We compute the simple average of respective policy variables for credit or stock market, each sub-index being normalized ( 0 for the "worst" country and 1 being the best" country ${ }^{26}$ ). Again, we find positive and significant coefficients for very small and small firms for both sets of variables.

\section{TABLE 6 HERE}

\footnotetext{
26 The difference between the maximum and the minimum of simple averages across countries is larger than 0.6 for both sets of variables. Note that similar results (but somewhat less significant for market) are obtained using the first principal component of each set of variables.
} 
In Table 6, we check the robustness of previous results (focusing on instrumented measures of financial development) while controlling for other policy variables, namely labor market regulation and entry costs, which are expected to have a negative impact on entry rates. Each of these policy variables is interacted with specific industry factors. In column (1), we control for employment protection legislation (EPL) interacted with the intensity of job flows in US. We find negative coefficients for EPL, that is to say, labor market regulation has a negative impact on entry rates in sectors characterized by larger job flows, i.e. where the EPL-induced overall costs of adjustment are higher given the stronger requirement to adapt the workforce to changes in demand. ${ }^{27}$ Although the impact of EPL is negative and significant for most size categories, the estimated impact of private credit (instrumented by policy variables) is still significant for small firms and slightly larger than before. Similarly, in column (2), where the effect of stock market (instrumented) is estimated along with EPL, results are similar if not even larger than without EPL. We also control for entry costs. In columns (3) and (4), we interact entry costs with firm turnover rates in US, following Fisman Allende (2004) and Klapper, Leaven and Rajan (2006). Surprisingly, we find non significant coefficients for entry costs. ${ }^{28}$ However, the impact of private credit and stock market (instrumented) is as large as previously estimated. In columns (5) and (6), entry costs are interacted with the growth potentials of the industry, proxied by the growth of value added in each US industry relative to the overall average. The estimated coefficients for entry cost are now negative but coefficients for financial development still hold (coefficients small firms are stronger and coefficients for very small firms are weaker).

Quantitatively, the difference of the impact of financial development between small and large firms is quite sensible. If we multiply the coefficients by the difference between the 90th and the 10th percentile of the industry factor and the difference between the highest and the lowest value of the country variable, we find that the impact of private credit on very small firms rises to 3.6 whereas the impact on large firms drops to -2 . It yields a differential impact of more than 5 percentage points. This effect is quite large compared to the mean entry rate in our sample, which ranges from $2.0 \%$ among the largest firms $(500+)$ to $9.4 \%$ among the smallest ( $<20$ employees). Independently, the impact of private credit on small firms seems larger than stock market but it becomes smaller once we control for EPL or entry costs. The Labor regulations also have a sizeable and comparable impact to that of financial development: the difference in firm entry between industries with a high job flexibility requirement and those with a low flexibility requirement will be 3.3 percentage points lower in a country with the highest index of EPL compared to the United States, the country with the least restrictive regulations. However, these policy variables do not seem to affect firms of different size differently, a feature that however characterizes clearly financial development.

All results presented in this section provide strong support to the predictions of our stylized model on entry. First, financial development has a strong positive impact on firm entry. Second, the effect is stronger for small firms and in sectors with greater dependence on external financing. For large firms, as indicated in the model, financial development may even

27 These results are consistent with those of Haltiwanger, Scarpetta and Schweiger (2006) who look at the impact of employment protection legislation on job flows using the same database.

28 This absence of negative coefficient is not sensible to the set of countries (except US), specifications, and measures of entry costs or firm turnover. Note that we drop the US from the regressions while using interactions with turnover in US, job flows in US and growth of value added in US, because these indices are strongly correlated with entry rates in US. Including US into the regressions with entry costs yields negative coefficients, but the coefficients for financial development still hold. 
deter entry of new firms. Third, these results are robust to the inclusion in the regressions of other regulatory factors that also influence the decision to enter the market. In particular, employment protection legislation, by raising adjustment costs of new firms, tends to reduce entry rates mainly in those sectors that are characterized by more volatility in employment. Similarly, there is only tentative evidence in our data that start-up costs affect negatively entry rates in dynamic sectors, ceteris paribus.

\section{Post-entry growth}

We now check the third prediction of our model, namely that financial development should promote post-entry growth, even after controlling for the initial size at entry. In Table 7, we present the results of our regressions with interactions of the indices of financial development with the dependence in external finance.

\section{TABLE 7 HERE}

In column (1), (2) and (3), the coefficients for financial development (the overall index, private credit over GDP and stock market capitalization over GDP, respectively) are all positive and significant. In other words, financial development promotes post-entry growth in sectors with higher dependence in external finance. Here the effect of stock market seems to dominate.

As previously, we also consider the impact of different policy variables that are likely to affect either banking or financial markets. In column (4), we instrument private credit by the share of government assets over total bank assets, barriers to the entry of foreign banks, entry requirements and the regulation of banking activity. In column (5), we instrument stock market capitalization by contract enforcement, creditor rights, public or private registries, investor protection and bankruptcy procedures. In both cases, the instrumentation yields better results in term of magnitude or significance. Again, effects of stock market and private credit are not statistically different if we multiply each coefficient by the variations of the component of the respective index of financial development as predicted by policy variables. Finally, coefficients are also positive and significant if we take the simple average of the respective set of policy variables (columns 6 and 7 of table 4).

\section{TABLE 8 HERE}

In table 8, we first examine whether the impact of financial development holds if we control for employment protection legislation (EPL) interacted with the intensity of job flows in the US industries (columns 1 and 2). We find an insignificant coefficient for EPL, while the coefficients of both private credit and stock market remain statistically significant. The next two columns (3 and 4) examine whether the positive impact of financial development holds if we control for the size at entry. As the model suggests (as soon as the initial and long term capacities are not perfectly correlated), ${ }^{29}$ post-entry growth should be larger for smaller entrants. Indeed, we find a strong, negative and significant for the size at entry. The coefficient for financial development, either credit or stock market, is slightly lower but still positive and significant. 
Last but not least, we need to assess whether financial development has a particular impact on entrants compared to incumbents. Unfortunately, the data does not allow following firms other than entrants over time. Nevertheless our data allow estimating the evolution in the average size of incumbent firms over time. ${ }^{30}$ Including this additional explanatory variable in our post-entry growth regression (Columns 5 and 6) does not affect significantly the coefficients for financial development.

Quantitatively, the impact of private credit and stock market capitalization on post-entry growth is sizeable. Using the same procedure discussed above for entry rates, we estimate the difference between industries with a high dependence on external financing $\left(90^{\text {th }}\right.$ percentile of distribution in the United States) and industries with a low dependence ( $10^{\text {th }}$ percentile of the same distribution) in a country with the highest index of financial development compared to the country with the lowest index. For private credit, we estimate that the effect will be around 36 percentage points compared to 43 percentage points for the effect of stock market capitalization.

These results provide strong support to the third prediction of our model. Financial development not only promotes the entry of new firms, but also the post-entry growth of successful firms, especially in those industries that depend more of external financing. Moreover, we find that post-entry growth is larger for cohorts with lower average size at entry and that, controlling by average size at entry, the positive impact of financial development is still positive and significant.

\section{Sensitivity analysis}

This section investigates the robustness of our results along different dimensions. Concerning entry, we first check the sensitivity of the results to the set of countries and additional controls, namely the share of employment of incumbents in the same industry/size cell within each country or the growth of the value added in the industry. We then analyze the impact of financial development according to the growth potential of the industry, interacting policy variables with the relative growth rate of the sector in the United States.

For the post-entry growth analysis, we compare our results with those referring to the average growth rate of incumbent firms. Indeed, we show that the impact of financial development on incumbent size growth is much weaker in term of amplitude or statistical significance than that on the growth of new firms. We also consider different durations for the analysis of post-entry growth and look at total employment changes of each cohort, instead of the growth of only surviving firms to account for survival and growth.

\section{Sensitivity to the set of countries and sectors}

30 The data on entry permits to distinguish between three categories of firms (in addition to the size category, year, industry and country): entering, exiting and continuing firms. The number of exiting firms plus continuing firms at date $t$ is equal to the number of entering plus continuing firms at data $t$ 1. The ratio of employment among these two groups of firms allows computing the growth in the average size of incumbent firms. 
In the empirical analysis, we control for country, industry and size effects, as well as for unobservable effects using a difference-in-difference approach. Moreover, we test the robustness of results using alternative measures of financial development and including various controls. However, the use of quasi panel data may still run the risk that results are driven by the inclusion of a specific country or industry in the sample that drives the results in a given direction.

To test for the robustness of results to changes in the sample, we re-estimate the most synthetic specification - columns (1) in Table 5 - removing one country or one industry at a time from the sample. Figures 7 and 8 present the estimated coefficients on financial development (sum of private credit and stock market) interacted with the dependence in external finance, differentiated by size classes.

The first set of results (figure 7) shows that the amplitude of our coefficient is quite sensible to the inclusion of US into the sample but, surprisingly, dropping the US actually amplifies the differences across size categories, which means that the coefficient for small firms (between 20 and 50 employees) increases and the coefficient for large firms decreases.

Figure 8 plots the sensitivity of the estimated coefficients of financial development to changes in the industry set. Removing one industry at the time does not lead to any major change in the estimated coefficients with the only exception of the R\&D sector, which is indeed the sector with the maximum value of external financial dependence. The main effect is to increase the standard deviation of the estimated coefficient, given that we reduce the variance of the interaction term. However, the coefficient remains positive and significant (at $5 \%$ level) for small and very small firms, lower and insignificant for larger firms.

FIGURE 7 HERE

FIGURE 8 HERE

\section{Additional controls}

Several studies (e.g. Rajan and Zingales 1998; Klapper et al., 2006) include the share of the industry in the total economy for each country in order to control for potential convergence effects across industries in a given country. To test for this hypothesis, we include in our entry regressions the share of employment of incumbents in each industry / size cell relative to the total employment of incumbents in the country. As expected, the corresponding coefficient is negative and significant, but does not affect the coefficients for financial development (see columns 1 and 2 in Table 9). If we compute the share of employment for the overall industry, instead of each industry /size cell, the resulting coefficient is negative but not significant and the coefficients for financial development still hold.

Similarly, in columns (3) and (4) we include the relative growth rate of value added of the industry to control for differences in growth opportunities (across years, countries and industries) that could directly affect entry rates. The coefficient for the control is slightly positive and coefficients for financial development hold. It shows that our results are not driven by the possibility that countries that are closer to the U.S. have higher growth opportunities in sectors that are more dynamic in the U.S. and more dependent in external finance. 
TABLE 9 HERE

Interaction with the potential growth of the sector

As a robustness check for the choice of the industry factor, we consider interaction of indices of financial development with the growth potential of each industry, measured by the value added growth of each industry relative to the average in the U.S. (as in Perotti and Volpin 2004). Under the assumption that the United States are at the frontier in many sectors and are characterized by limited regulations that affect entry and post entry growth, this interacting factor should proxy for the technological and market driven potentials of the sector in the absence of policy-induced frictions. We drop observations for the US from the regressions. As shown in columns (5) and (6) of Table 6, we obtain positive and significant coefficients of financial development for small firms, that is to say, financial development boosts the entry by small firms in sectors with higher growth potentials. ${ }^{31}$ The coefficients for larger firms are slightly negative but not significant. These regressions complement and support the robustness of our findings by interacting financial development and the dependence in external finance.

\section{Impact of financial development on incumbent size growth}

As mentioned in the result section on post-entry growth, the data does not allow following incumbents during 6 years and directly comparing the growth of entrants versus incumbents. This would have been the simplest way to assess whether financial development has a higher impact on entrants compared to incumbents. However, we can compute the growth of the average size of all surviving firms from one year to another. In columns (1) and (2) (Table 10) we show that financial development has only a weak and non significant effect on the average size growth. Even if we multiply this coefficient by 6 (post-entry growth is measured after 6 years), the estimated effect is much weaker than for entrants ${ }^{32}$. These results support a stronger impact of financial development on entrants compared to incumbents and complement the results from columns (5) and (6) in table 5 where incumbent size growth is just a control.

\section{TABLE 10 HERE}

\section{Post-entry growth after different durations}

As stressed above, we are interested in assessing the role of financial development on post entry growth once we allow for natural learning by doing and market selection. As a robustness check, we consider shorter duration periods. This allows considering cohorts of larger size but also implies using potentially more noisy data, as these cohorts still include firms in the early stages of life with strong learning by doing. In columns (3) and (4) of table 7 , we show that our results hold if we look at post-entry growth after 5 years. However, the impact of financial development is less significant if look at post-entry growth after 3 years (columns 5 and 6) or less. According to the model, it suggests that the long-term capacity and

31 Similar but less significant results are found if financial development is interacted with entry rates in US in the same sector, (see Klapper, et al. 2006 for a similar approach). 
the effect of investment in expansion are revealed after several years only. We also checked whether our results hold if we look at post-entry growth after 7 years, at the cost of reducing the number of countries in the regressions (cohorts in some countries are not documented after more than 6 years). The resulting coefficients for financial development are robust also in this case.

\section{Accounting for survival: total employment growth}

Last but not least, we analyze the impact of policy variables on the total employment growth of cohorts instead of the growth of the size of surviving firms. In columns (7) and (8) in table 7 , we reproduce the regressions on financial development using the total employment growth of the cohort instead of the growth of the size of surviving firms. Our coefficients for financial development interacted with dependence in external finance are still positive and significant. It supports the idea that selection occurs at least partially before entry, as described in the model, or that the effect investment in post-entry expansion dominates.

\section{Conclusions and policy considerations}

In this paper, we used a harmonized firm-level database to assess the role of financial development on firm entry, the size at entry and post entry performance of new firms. We implemented a difference-in-difference approach in which we test whether those industries with greater dependence on external financing experience greater firm dynamism in countries with more developed financial markets. We proxy financial development with outcomes measures (private credit and stock market capitalization) but also instrument them with regulatory indicators of banking and securities markets. Since entry and post-entry growth of new firms are likely to depend on a host of other factors, in our empirical analysis we also consider start-up regulations and employment protection legislation that, by raising entry costs or labor adjustment costs, may discourage entry and post-entry growth.

A first finding of our empirical analysis is that finance matters most for the entry of small firms, especially in sectors that are more dependent upon external finance. This should not come as a big surprise: small firms are those who face the largest financial constraints, as discussed in several papers (e.g. by Bernanke and Gertler, 1990, World Bank, 2005). But our findings also imply that finance helps improve the selection process by allowing small firms to compete on a more equal footing with large firms. More finance permits small firms to take advantage of growth opportunities especially in growing sectors where large firms would be predominant otherwise. Higher entry in turn can be shown to be growth-enhancing, as entrants can force inefficient incumbents to exit or force efficient ones to innovate (see Aghion et al., 2006).

A second finding is that financial development improves post-entry growth of firms. Of course, one might argue that higher post-entry growth mainly reflects a better selection at entry and the improved access to credit for smaller entrants. However, we saw that the positive impact of financial development on post-entry growth holds if we try to control for the size of entrants.

A third finding is that our results are robust to the inclusions of other regulations that may also affect entry and post-entry growth. While there is evidence that stringent employment 
protection legislation affects the entry of firms in more volatile sectors, the impact of this legislation on post entry growth is not clear cut.

Fourth, while our results suggest that both private credit and stock market capitalization are important for promoting entry, the latter plays a stronger role for post-entry growth. This result is consistent with the view that market-based financing has a crucial role for boosting investment in capacity expansion. Indeed several studies have stressed the in bank-based systems the links between lenders and small borrowers tend to be weaker and potentially less effective especially in the case of innovative start-ups. ${ }^{33}$ While the development of stock markets depends on the level of development of the country, several studies have also highlighted the significant role of legal systems (civil vs. common law) as well as other factors that are more amenable to policy interventions, such as accounting standards and regulations (Demirguc-Kunt and Levine, 1999).

Based on our findings, a main policy indication is that many countries, including those in Continental Europe, should probably make further progress in improving their financial markets, so as to boost aggregate entry, and particularly the entry of small firms, to better select the best projects, and to promote post-entry growth of successful new firms. Other regulations also have an impact on entry and on specific sectors (e.g. highly volatile sectors in the case of employment protection) but seem to have a weaker role in driving post entry growth. Further promoting financial reforms aimed at fostering competition while maintaining stability objectives may have strong overall effects on growth performance, without necessarily facing the strong opposition as in the case of, for example, reforms in labor regulations.

Our empirical results provide only tentative indications of the direction of further reforms in financial markets and it is, of course, beyond the scope of this paper to provide any specific policy recommendation. However, drawing from available summary indicators of regulations in banking and securities markets, there is clear evidence that there is a long way to go in several countries. Many of them have undertaken significant deregulations over the past decade, and improvements in information and communication technologies have raised competitive pressures in most segments of financial markets. Nevertheless, there remain significant differences in the stringency of regulations, even across the OECD countries in our sample. These differences are likely to affect the degree of competition in the banking sector and securities markets and raise the costs and choices for both savers and users of external finance.

Our results also suggest that in several ways, stock market capitalization and equity play an important role, especially in term of post-entry growth. And here the gap between the U.S., the U.K. and some Nordic countries on the one hand, and many Continental E.U. countries

Stein (2002), for example, has argued that the difficulty to lend effectively to small borrowers is in the nature of being a bank. The tendency for banks to be large increases the distance between the owners and the loan officers who deal with small borrowers. And, to minimize risks, large banks tend to restrict the discretion of the loan officers (i.e. by making rules based on easily measured characteristics of the borrower). This, he argues, while covering the bank, may make the lending to small firms more difficult and less effective. A recent survey conducted by the OECD also finds no strong evidence of a "financing gap" for SME. But lack of appropriate financing is a hindrance to the expansion of the innovative SMEs, i.e. firms in technology sectors, with new business models and high growth prospects. Traditional bank finance may be of little relevance for these firms, as they have untried business models and high risk. (see OECD, 2006). 
and emerging economies tends to be considerable. In 2003, for example, stock market capitalization over GDP was equal to 0.64 for EU 15 versus 1.17 for the U.S.. Moreover, evidence that financial constraints is especially high for new (small) entrants who may have limited means of internal finance has led to policy programs targeting fiscal support directly at small firms, and also to measures designed to encourage the development of venture capital markets. However, there are still major differences in venture capital investment across the OECD countries. For example, venture capital investment accounts for slightly less than 0.5 percent of GDP in the U.S. but by less than 0.15 percent in Germany, France, Spain or Italy.

\section{Bibliography}

Aghion, P and P. Howitt (2006), "Appropriate Growth Policy: A Unifying Framework", Journal of the European Economic Association, 4, 269-314

Aghion, P and R. Griffith (2005), Competition and Growth, MIT Press

Aghion, P, Banerjee, P, and T. Piketty (1999), "Dualism and Macroeconomic Volatility", Quarterly Journal of Economics, 114, 1359-1397.

Aghion, P, Burgess, R, Redding, S and F. Zilibotti (2006), "The Unequalizing Effect of Liberalization: Evidence from Dismantling the License Raj in India", NBER Working Paper 12031.

Ahn, S. (2000). "Firm dynamics and Productivity Growth: A Review of Micro Evidence from OECD Countries." OECD Economics Department Working Paper No. 297, Paris.

Albuquerque, R. and H. A.. Hopenhayn (2004). "Optimal Lending Contracts and Firm Dynamics," Review of Economic Studies, Blackwell Publishing, vol. 71(2), pp. 285-315.

Alfaro, L and A. Charlton (2006), "International Financial Integration and Entrepreneurship, Harvard Business School Working Paper No. 07-012.

Bartelsman, E, Haltiwanger, J, and S. Scarpetta (2004), "Microeconomic Evidence of Creative Destruction in Industrial and Developing Countries", IZA Discussion Papers No 1374

Bartelsman, E, Haltiwanger, J, and S. Scarpetta (2005), "Measuring and Analyzing Cross-Country Differences in Firm Dynamics", mimeo World Bank

Bartelsman, E, Scarpetta, S, and F. Schivardi (2005), "Comparative Analysis of Firm Demographics and Survival: Evidence from Micro-Level Sources in OECD Countries", Industrial and Corporate Change, $14,365-391$

Bartelsman, E. J. and M. Doms (2000). "Understanding Productivity: Lessons from Longitudinal Microdata." Journal of Economic Literature 38(3), pp. 569-95.

Barth, J. R.G., Caprio, and R.E. Levine (2001), "Bank Regulation and Supervision: What Works Best?", Univ. of Minnesota, Carlson School of Management; World Bank Policy Research Working Paper No. 2725.

Beck, T, Demirguc-Kunt, A, and R. Levine (2000), "A New Database on Financial Development and Structure", World Bank Economic Review, 14, 597-605.

Beck, T., A. Demirguc-Kunt, L. Laeven, and R.E. Levine (2004), "Finance, Firm Size, and Growth" NBER Working Paper No. W10983.

Beck, T., Demirgüç-Kunt, A., Maksimovic, V., (2004), "Financial and Legal Constraints to Firm Growth: Does Size Matter?", Journal of Finance 60, pp. 137-177.

Bernanke B. S, M. Gertler (1990),"Financial Fragility and Economic Performance", Quarterly Journal of Economics, February 1990, vol. 105, no. 1, pp. 87-114.

Bertrand, M. and F. Kramarz (2002), "Does Entry Regulation Hinder Job Creation? Evidence from the French Retail Industry," IZA Discussion Papers 415. 
Bertrand, M., A. Schoar and D. Thesmar (2007), "Banking Deregulation and Industry Structure: Evidence from the French Banking Reforms of 1985," The Journal of Finance (forthcoming).

Botero, J. C., S. Djankov, R. La Porta, F. Lopez-de-Silanes and A. Shleifer (2002), "The regulation of Labor," Quarterly Journal of Economics, November 2004, vol. 119, no. 4, pp. 1339-1382.

Caballero, R., K.N. Cowan, E.M.R.A. Engel and A. Micco (2004). "Effective Labor Regulation and Microeconomic Flexibility"', Discussion Paper 1480, Cowles Foundation, September 2004.

Cabral, L.M. B. and j. Mata (2003). "On the Evolution of the Firm Size Distribution: Facts and Theory," American Economic Review, American Economic Association, vol. 93(4), pp. 1075-1090,

Caves, R.E. (1998). "Industrial Organization and New Findings on the Turnover and Mobility of Firms." Journal of Economic Literature 36:4, pp. 1947-82.

Cetorelli, N. and P.E. Strahan (2004), "Finance as a Barrier to Entry: Bank Competition and Industry Structure in Local U.S. Markets", FRB of Chicago Working Paper No. 2004-04.

Ciccone A. an E. Papaioannou (2006), "Adjustment to target capital, Finance, and Growth", University Pompeu Fabra mimeo.

Claessens, S., and L. Laeven. 2003. "Financial Development, Property Rights, and Growth.” Journal of Finance 58(6): pp. 2401-36.

Clementi, G. and H. Hopenhayn (2006), “A Theory of Financing Constraints and Firm Dynamics”, Quarterly Journal of Economics, Volume 121, Issue 1, February 2006, pages 229-265

Davis, S. and J. Haltiwanger (1999). "Gross Job Flows.” in David Card and Orley Ashenfelter eds. the Handbook of Labor Economics, North-Holland.

de Serres, A. S. Kobayakawa, T. Slok and L. Vartia (2006), "Regulation of Financial Systems and Economic Growth", OECD Economics Department Working Papers, No. 506, OECD Publishing.

Demirguc-Kunt, Asli and R.E. Levine, (1999), "Bank-Based and Market-Based Financial Systems: CrossCountry Comparisons" (July), World Bank Policy Working Paper No. 2143.

Desai, M.A. P.A. Gompers and J. Lerner (2003) "Constraints and Entrepreneurial Firm Dynamics: Evidence from Europe", NBER Working Paper No. 10165

Djankov, C. McLiesh and A. Shleifer (2007), "Private Credit in 129 Countries", Journal of Financial Economics, May, 2007.

Djankov, S, La Porta, R, Lopez-de-Silanes, F, and A. Shleifer (2002), "The Regulation of Entry", Quarterly Journal of Economics, 117, 1-37.

Dunne, T., M. Roberts and L. Samuelson (1988). "Patterns of Firm Entry and Exit in US Manufacturing Industries." Rand Journal of Economics 19:4, pp. 495-515.

Dunne, T., M. Roberts and L. Samuelson (1989). "The Growth and Failure of U.S. Manufacturing Plants." Quarterly Journal of Economics 104, pp. 671-98.

Eurostat (1998). Enterprises in Europe, Data 1994-95. Fifth Report of the European Commission, EUROSTAT, Luxembourg, 1998

Evans, D. (1987a). "The relationship between firm growth, size and age: Estimates for 100 manufacturing industries.” Journal of Industrial Economics 35:4 (June), pp. 567-581.

Evans, D. (1987b). "Tests for alternative theories of firm growth.” Journal of Political Economy 95:4 August, pp. 657-674.

Evans, D.S. and B. Jovanovic. (1989). "An Estimated Model of Entrepreneurial Choice Under Liquidity Constraints," Journal of Political Economy. 97, 808-827.

Fishman, R. and V. Sarria-Allende (2004). Regulation of entry and the Distortion of industrial organization. Working Paper No. 10929. Cambridge, MA: NBER.

Foster, L. J.C. Haltiwanger and C.J. Krizan (2001) Aggregate Productivity Growth: Lessons from Microeconomic Evidence. In Edward Dean, Michael Harper, and Charles Hulten, editors, New Developments in Productivity Analysis, University of Chicago Press, 2001. 
Foster, L., J.C. Haltiwanger and J. Krizan (2006), "Market Selection, Restructuring and Reallocation in the Retail Trade Sector in the 1990s," Review of Economics and Statistics, (November).

Geroski, P (1995), "What Do We Know About Entry?", International Journal of Industrial Organization, 13, 421-440.

Griliches, Z. and H. Regev (1995). "Firm Productivity in Israeli Industry: 1979-1988." Journal of Econometrics_65:1 (January), pp.175-203.

Guiso, L., P. Sapienza and L. Zingales (2006). "The Cost of Banking Regulation," CEPR Discussion Papers 5864.

Gwartney J., and R. Lawson 2004. "Economic Freedom of the World - 2005 Annual Report", Fraser Institute, Vancouver, B.C., 2004

Haltiwanger, J., R. Jarmin, and T. Schank, (2003) "Productivity, Investment in ICT and Market Experimentation: Micro Evidence from Germany and the U.S., Center for Economic Studies Working Paper.

Haltiwanger, J., S. Scarpetta, H. Schweiger (2006), “Assessing Job Flows across Conutries: The Role of Industry, Firm Size and Regulations”, World Bank Policy Research Working Paper No. 4070.

Hubbard, G., (1998), “Capital Market Imperfection and Investment,” Journal of Economic Literature, XXXVI (1998), pp. 193-225

Klapper, L, L. Laeven and R. Rajan (2006), "Entry Regulation as a Barrier to Entrepreneurship", Journal of Financial Economics, 82, pp. 591-629.

La Porta, R, F. Lopez-de-Silanes and A. Shleifer (2002). Government Ownership of Banks. Journal of Finance, LVII , (1), pp. 265-302.

Levine, R. (2005) "Finance and Growth: Theory and Growth", in P. Aghion and S. Durlauf eds. Handbook of Economic Growth, Elsevier, 2005.

Lloyd-Ellis H, and D. Bernhardt (2000), "Enterprise, Inequality, and Economic Development". Review of Economic Studies, 67(1):, pp. 147-168.

Micco, A. and C. Pages (2006), "The Economic Effects of Employment Protection: Evidence from International Industry-Level Data”, IZA Discussion Papers No. 2433.

Micco, A., U. Panizza and M. Yañez (2004). "Bank Ownership and Performance," RES Working Papers 1016, Inter-American Development Bank, Research Department.

OECD (2006), “The SME Financing Gap”, OECD, Paris.

Olley, G. S. and A. Pakes (1996). "The Dynamics of Productivity in the Telecommunications Equipment Industry." Econometrica, 64:6, pp. 1263-97.

Pakes, A. and R. Ericson (1998). "Empirical Implications of Alternative Models of Firm Dynamics.” Journal of Economic Theory 79:1, pp. 1-45.

Pelgrin, F., S. Schich and A. de Serres (2002), "Increases in Business Investment Rates in OECD Countries in the 1990s: How Much Can Be Explained by Fundamentals?", OECD Economic Department Working Papers No. 327.

Perotti E. and Volpin P. (2004), "Lobbying on Entry", CEPR Discussion Paper 4519.

Pierre G. and S. Scarpetta (2006) "Employment Protection: Do Firms' Perceptions Match with Legislation?", Economics Letters 90(3), 328-334.

Rajan, R and L. Zingales (1998), "Financial Dependence and Growth", American Economic Review, 88, 559586.

Scarpetta, S. , P. Hemmings, T. Tressel and J. Woo (2002). "The Role of Policy and Institutions for Productivity and Firm Dynamics: Evidence from Micro and Industry Data," OECD Economics Department Working Papers 329, OECD.

Stein, J. (2002), "Information Production and Capital Allocation: Decentralized versus Hierarchical Firms", Journal of Finance, 57(5), 1891-1921. 
Stein, J. (2003), "Agency, Information, and Corporate Investment," in Handbook of Economics of Finance, Amsterdam, Elsevier North-Holland,.

Sutton, J (1997), "Gibrat's Legacy", Journal of Economic Literature, 35, 40-59.

World Bank (2004), "World Development Report: A Better Investment Climate - for Everyone", World Bank, Oxford Univ. Press. 


\section{Appendix: Impact of financial development on price and size}

Let $S(\mu p, p)$ denote the aggregated supply of the consumption good at price $p$ given the level of financial development $\mu$. Supply at time $t$ is equal to the sum of initial capacity of firms that entered at time $t$ and the long-term capacity of firms that entered at time $t-1$, accounting for capacity expansion (as soon as $\alpha>0$ ):

$$
S(\mu p, p)=\frac{1}{\bar{\theta}_{0} \bar{\theta}_{1}} \int_{\frac{b}{\mu p}}^{\bar{\theta}_{0}} \int_{\frac{b}{\delta p}}^{\bar{\theta}_{1}}-\frac{\theta_{0}}{\delta}\left(\theta_{0}+\theta_{1}\right) d \theta_{1} d \theta_{0}+\frac{1}{\bar{\theta}_{0} \bar{\theta}_{1}} \int_{\frac{b}{\mu p}}^{\bar{\theta}_{0}} \int_{\frac{1}{\alpha \delta p}}^{\bar{\theta}_{1}}\left(\mu p \theta_{0}-b\right) \alpha \theta_{1} d \theta_{1} d \theta_{0}
$$

Both terms are increasing with $p$ and $\mu p$. Given $\mu$, the equilibrium price $p^{*}$ is the unique solution of the equation:

$$
D(p)=S(\mu p, p)
$$

Since the right-hand-side is increasing in $\mu$, we immediately get that the overall supply is increasing in $\mu$, that the equilibrium price $p^{*}=p^{*}(\mu)$ is decreasing in $\mu$. In turn, combining these two facts leads to the conclusion that $p \mu$ is necessarily increasing in $\mu$. More precisely:

$$
\frac{d p^{*}}{d \mu}=-\frac{p^{*} S_{1}}{\mu S_{1}+S_{2}-D^{\prime}}<0
$$

(the lower is the demand elasticity the stronger is the impact of financial development on prices) and:

$$
\frac{d\left(\mu p^{*}\right)}{d \mu}=\frac{\left(S_{2}-D^{\prime}\right) p^{*}}{\mu S_{1}+S_{2}-D^{\prime}}>0
$$

which means that the initial size threshold is unambiguously decreasing with $\mu$. 
Figure 1:

Firm turnover rates in broad sectors, 1990s

A: $\quad$ Total business sector, firms with 20 or more employees

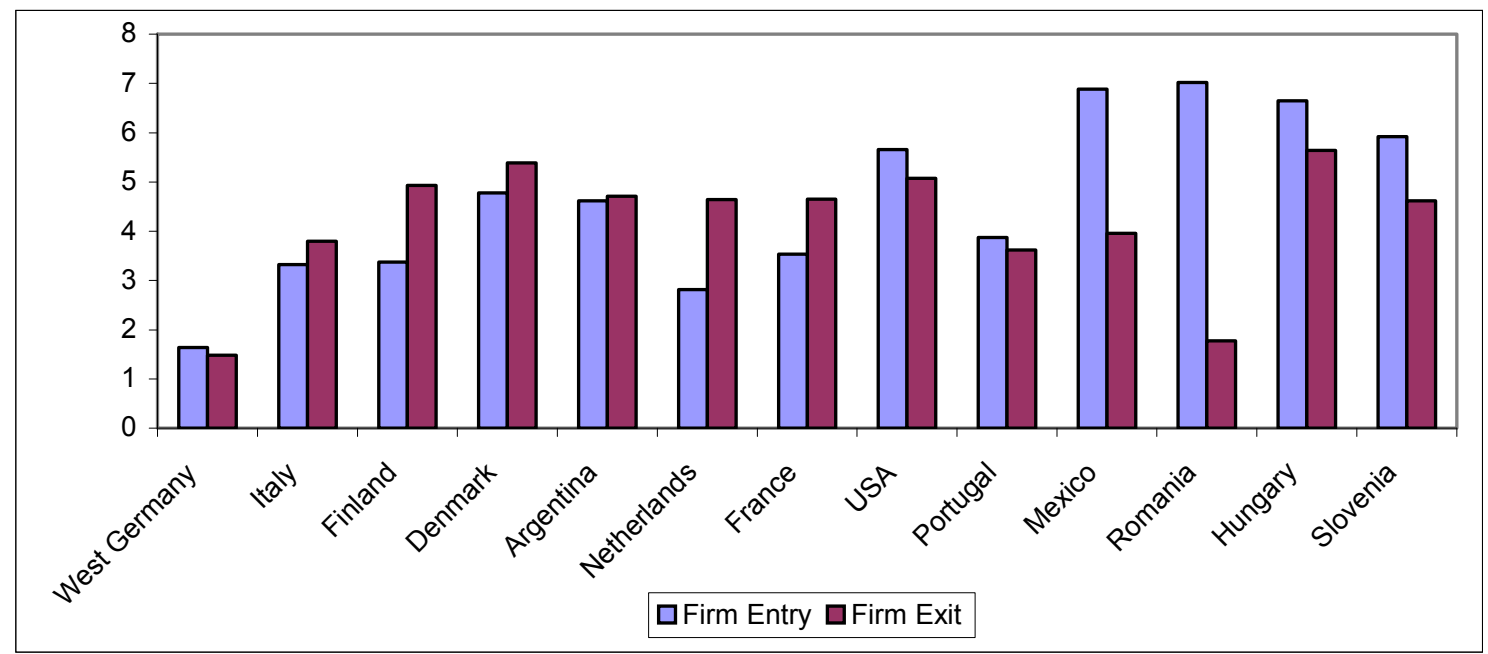

B: Manufacturing, firms with 20 or more employees

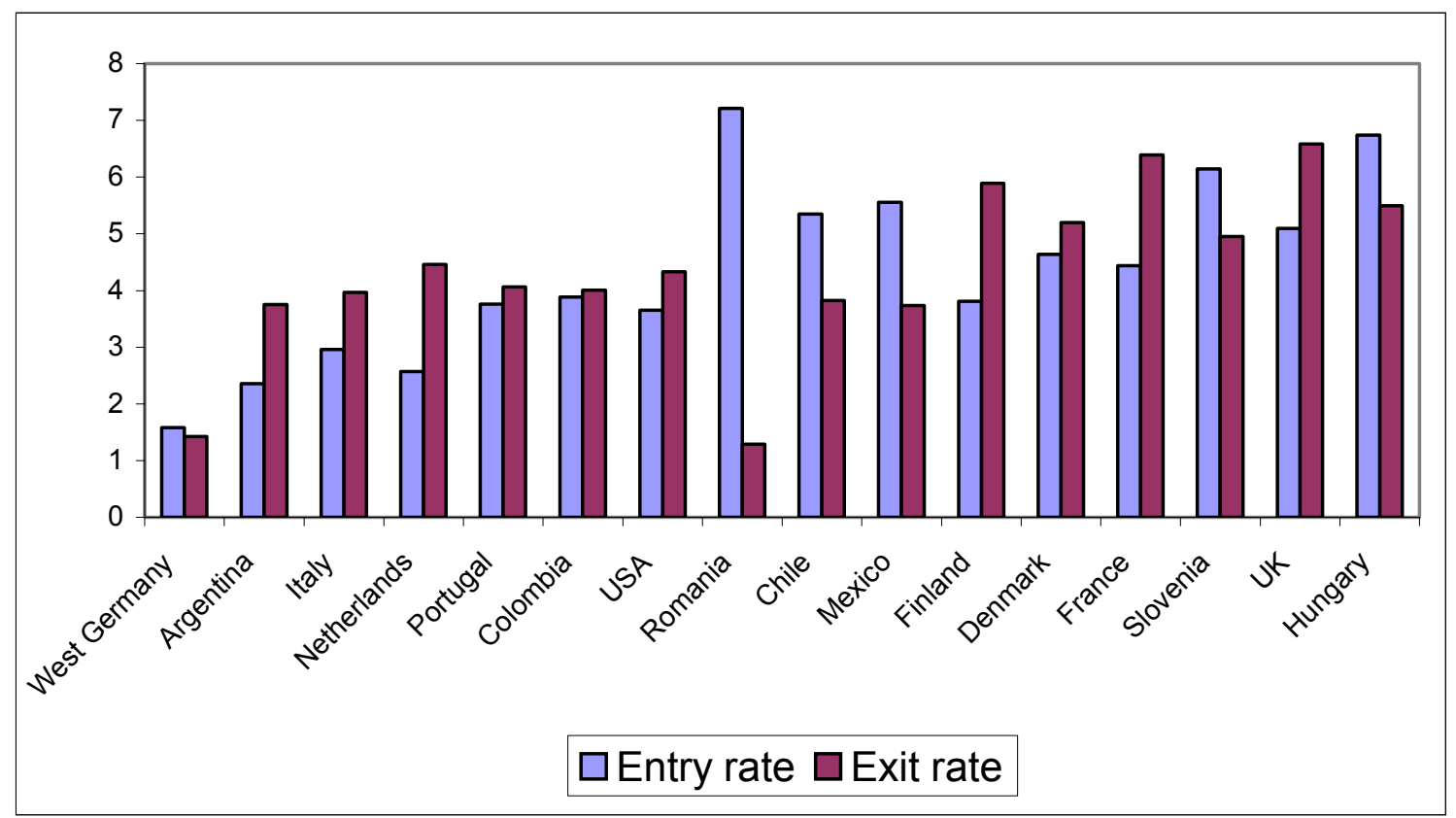

Source: Bartelsman, Haltiwanger and Scarpetta, 2004. 
Figure 2:

Firm survival in manufacturing at different lifetimes, 1990s

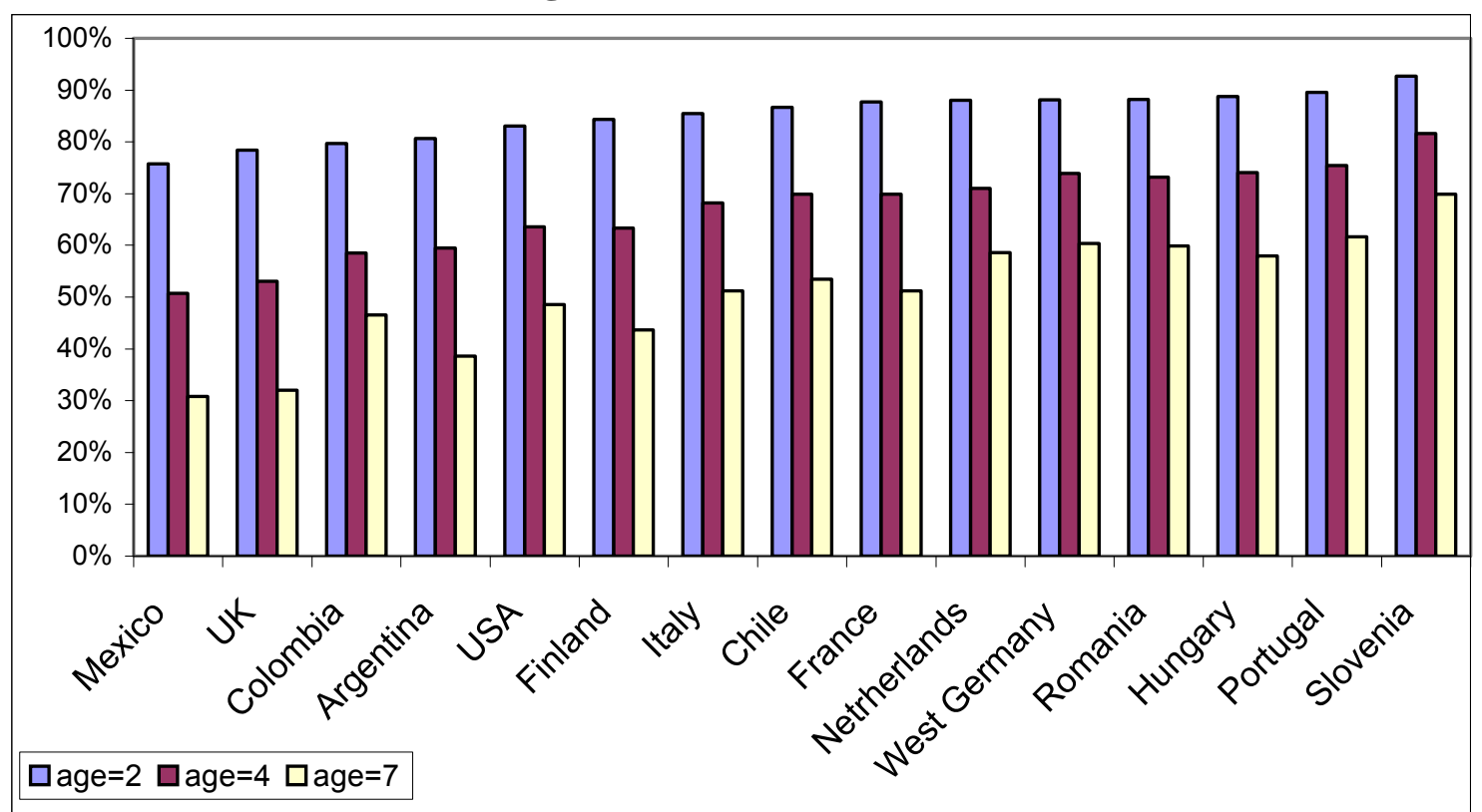

Source: Bartelsman, Haltiwanger and Scarpetta, 2004.

Figure 3:

Post-entry growth of successful firms

(Average firm size relative to entry, by age)

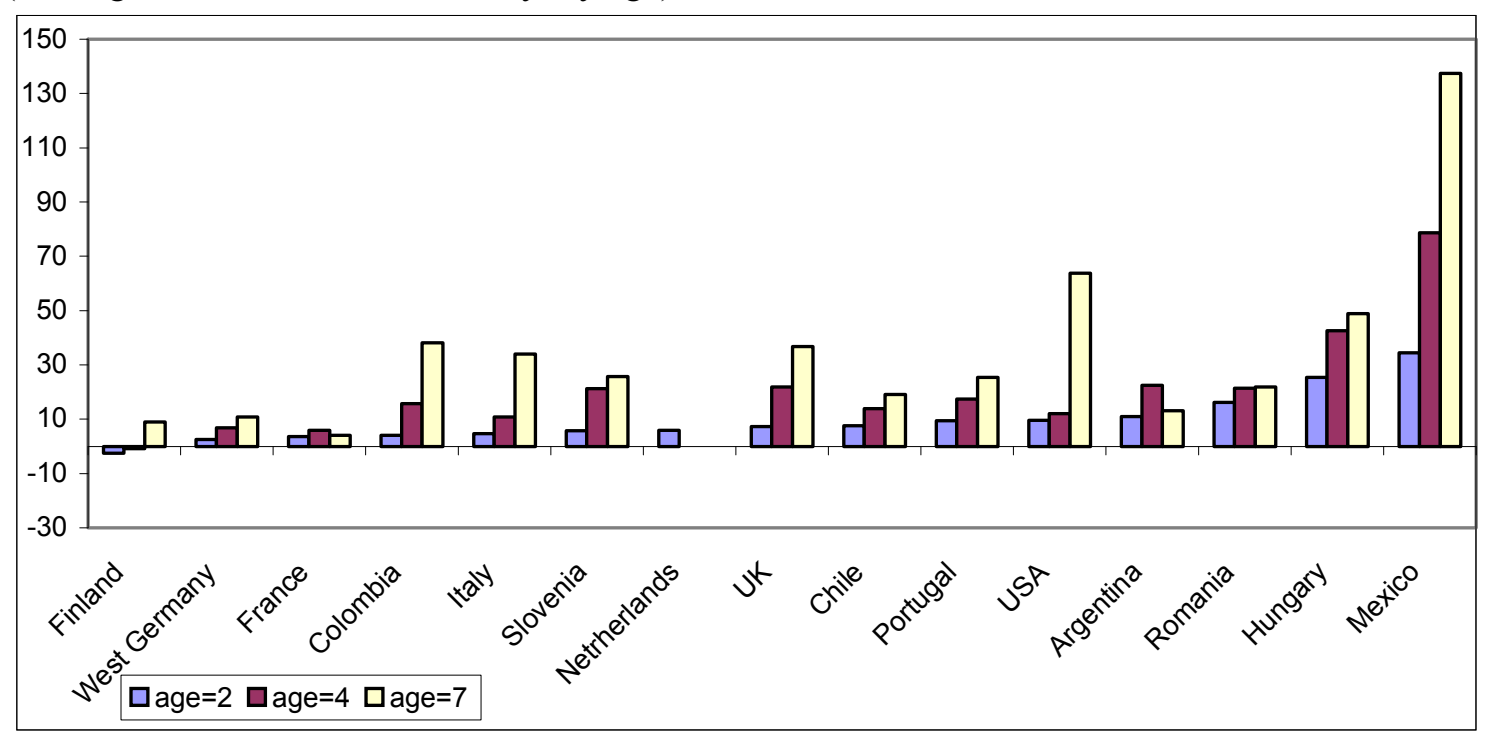

Source: Bartelsman, Haltiwanger and Scarpetta, 2004. 
Figure 4:

Impact of an increase of $\mu$ (index of financial development) on the composition of entry

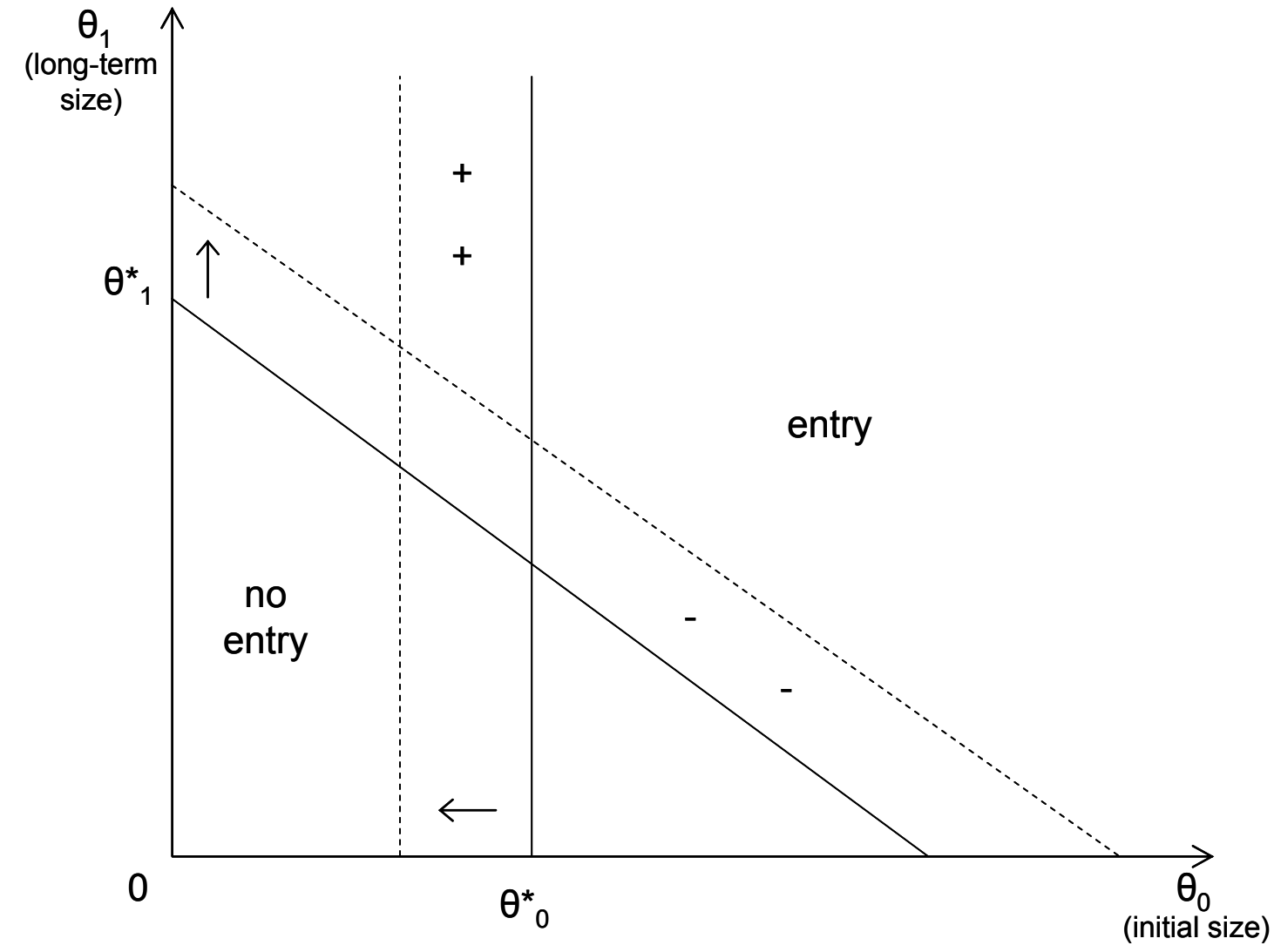


Figure 5: Indices on credit and banking regulations

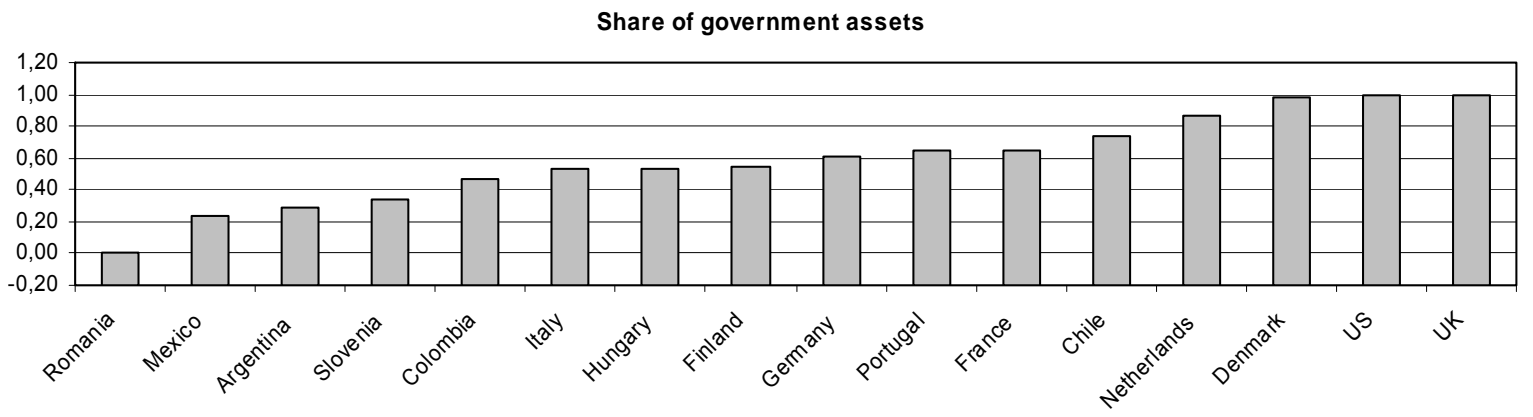

Barriers to foreign entry

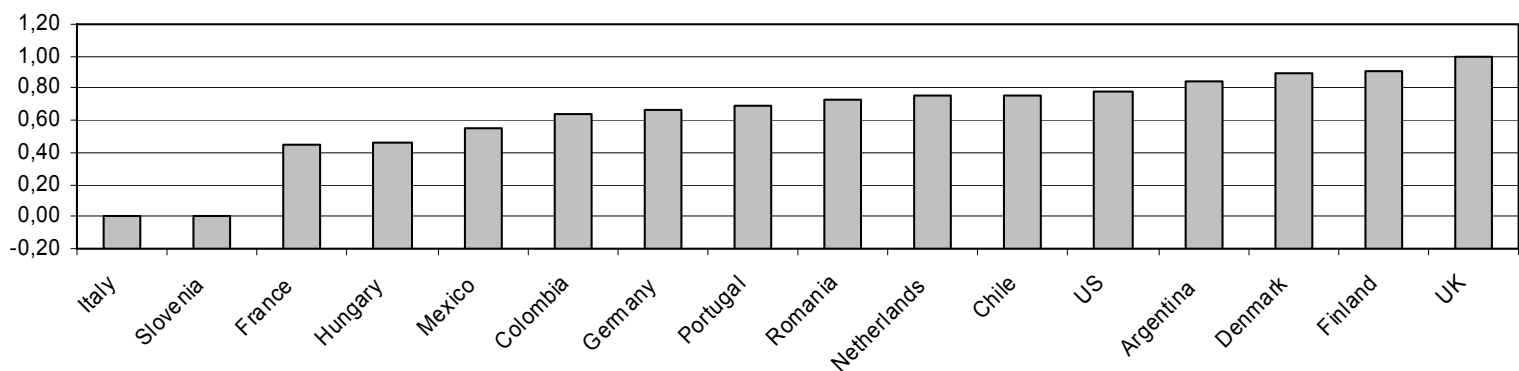

Entry requirements

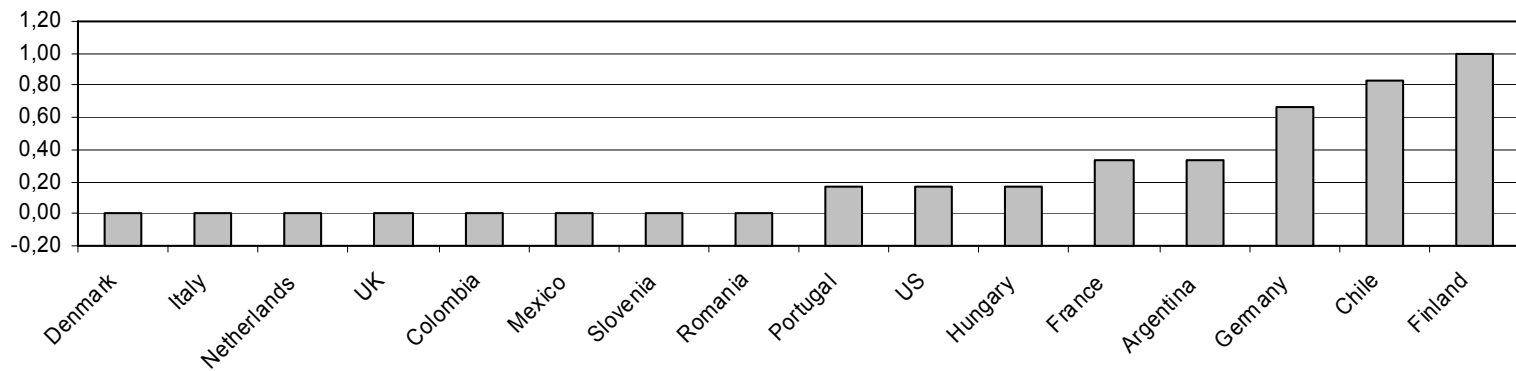

Regulation of Activity

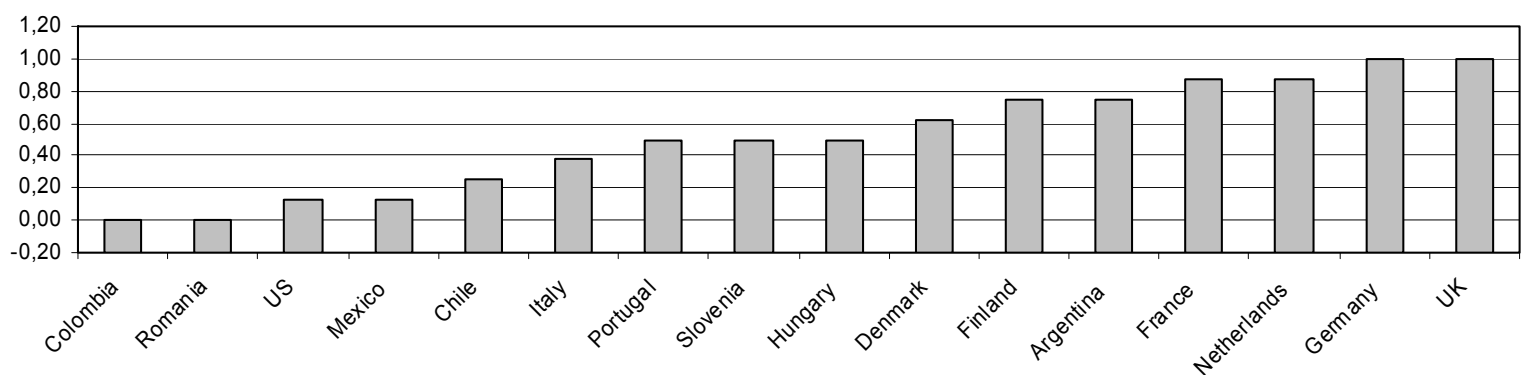

All indices have been rescaled from zero to one, one being for the "best performing" country.

Sources: Share of government assets (Micco, Panizza and Yanez 2004); Barriers to banking competition

(Gwartney and Lawson, 2004); Entry requirements and regulation of activity (Beck, Caprio and Levine, 2006). 
Figure 6: Security markets regulations indices

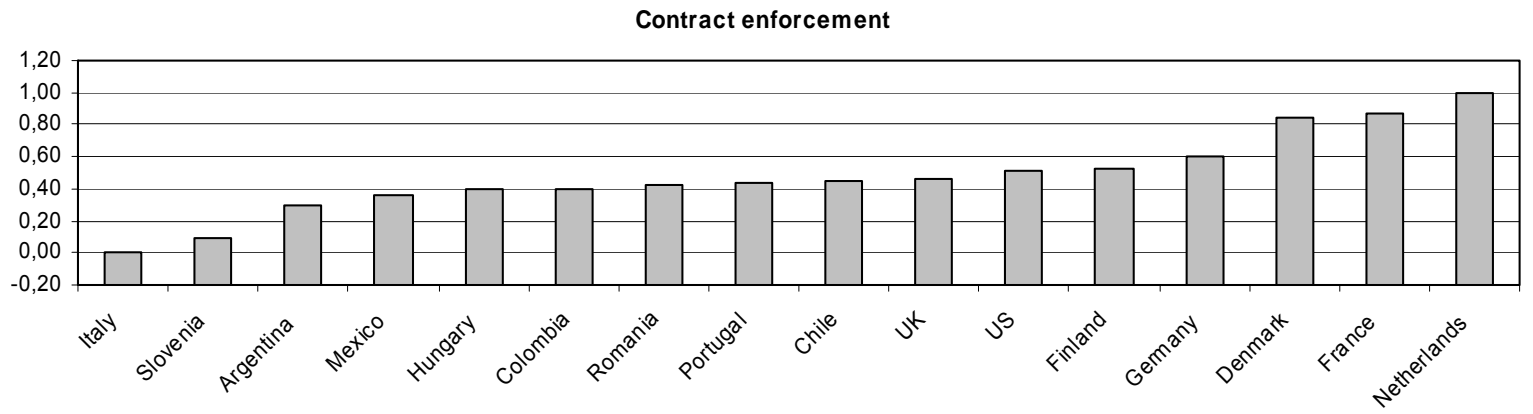

Creditor rights

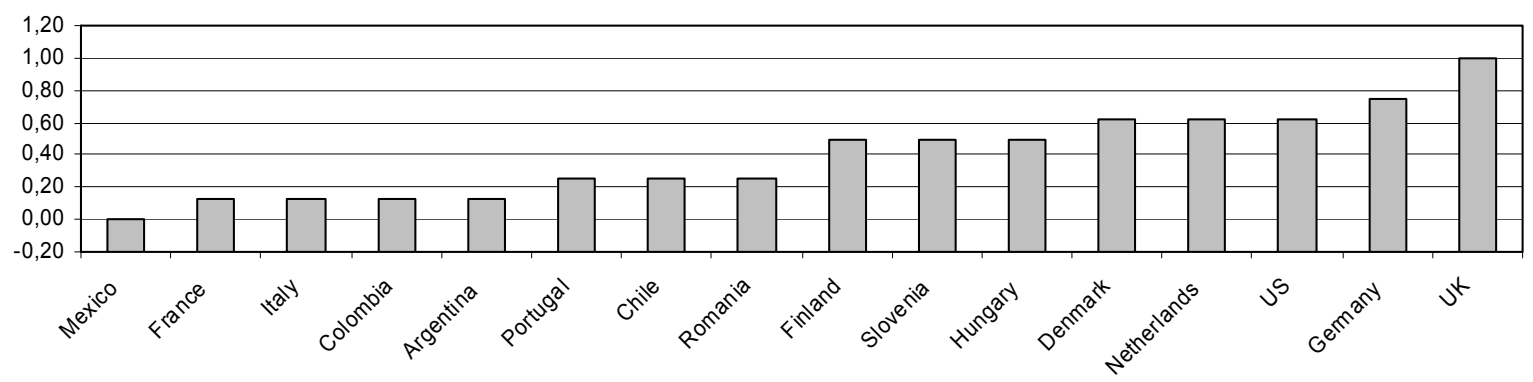

Public or private registries

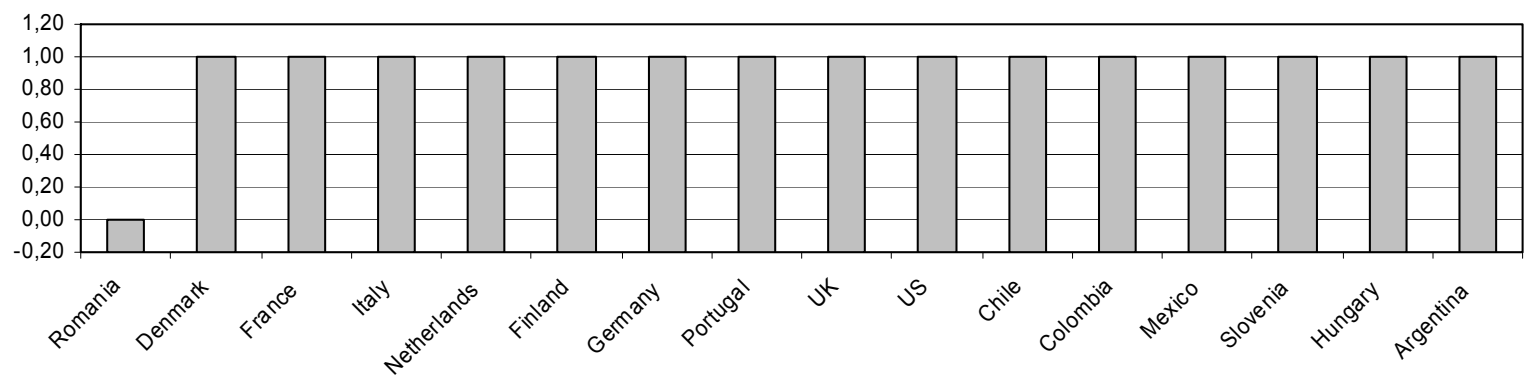

Investor protection

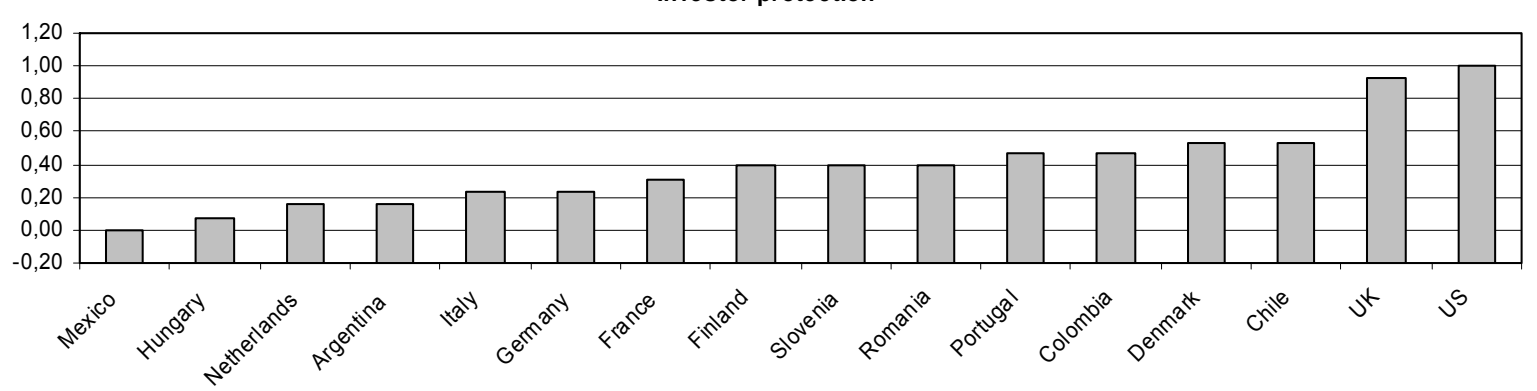

Bankruptcy procedures

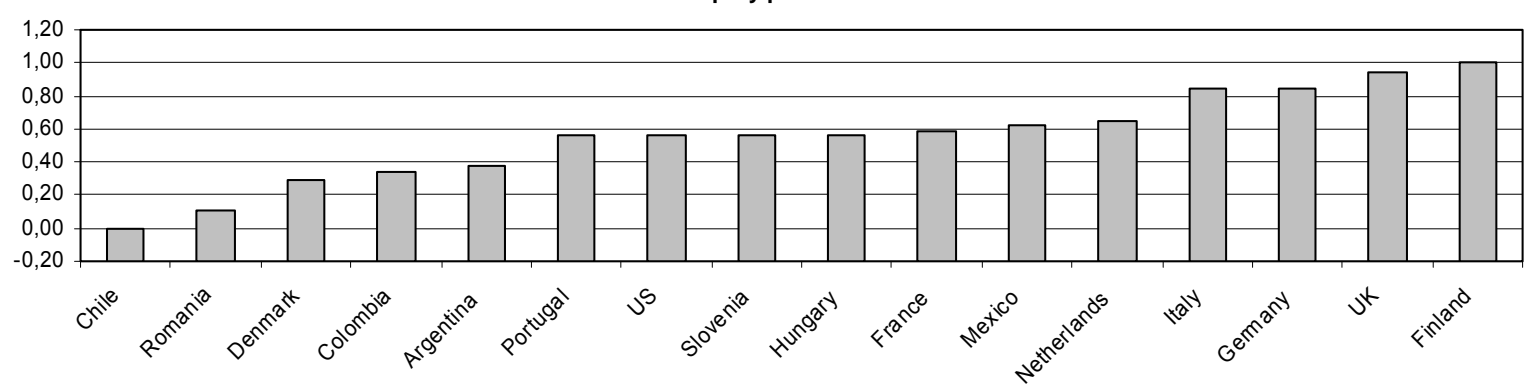

All indices have been rescaled from zero to one, one being for the "best performing" country.

Sources: Creditor rights, investor protection, bankruptcy procedures (World Bank: Doing Business database);

Public or private registries, contract enforcement (Djankov, MacLiesh and Shleifer 2006). 
Figure 7: Sensitivity analysis: Estimated coefficient (and 95-5\% confidence intervals) for financial development interacted with the index of dependence in external finance, by size (columns 1 of table 5), excluding one country at a time.
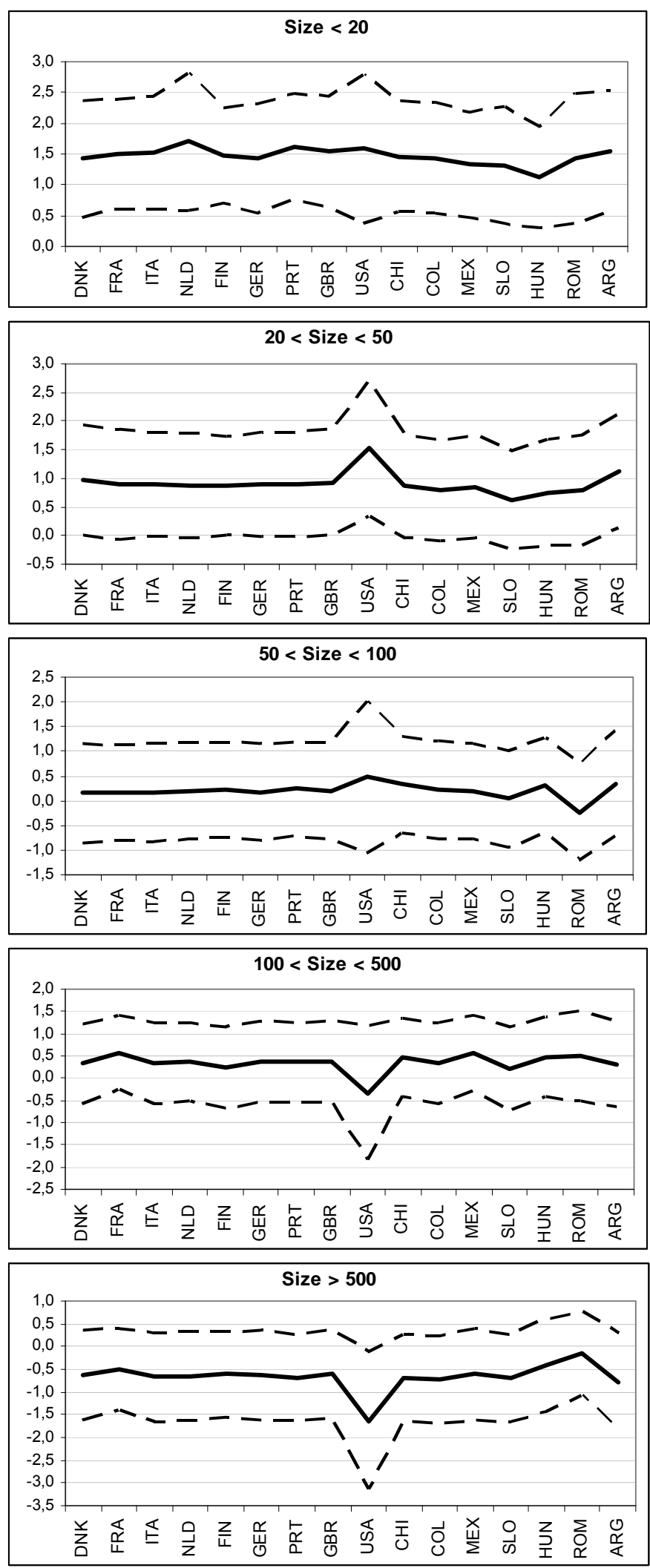
Figure 8: Sensitivity analysis: Estimated coefficient (and 95-5\% confidence intervals) for financial development interacted with the index of dependence in external finance, by size (columns 1 of table 5), excluding one sector at a time.
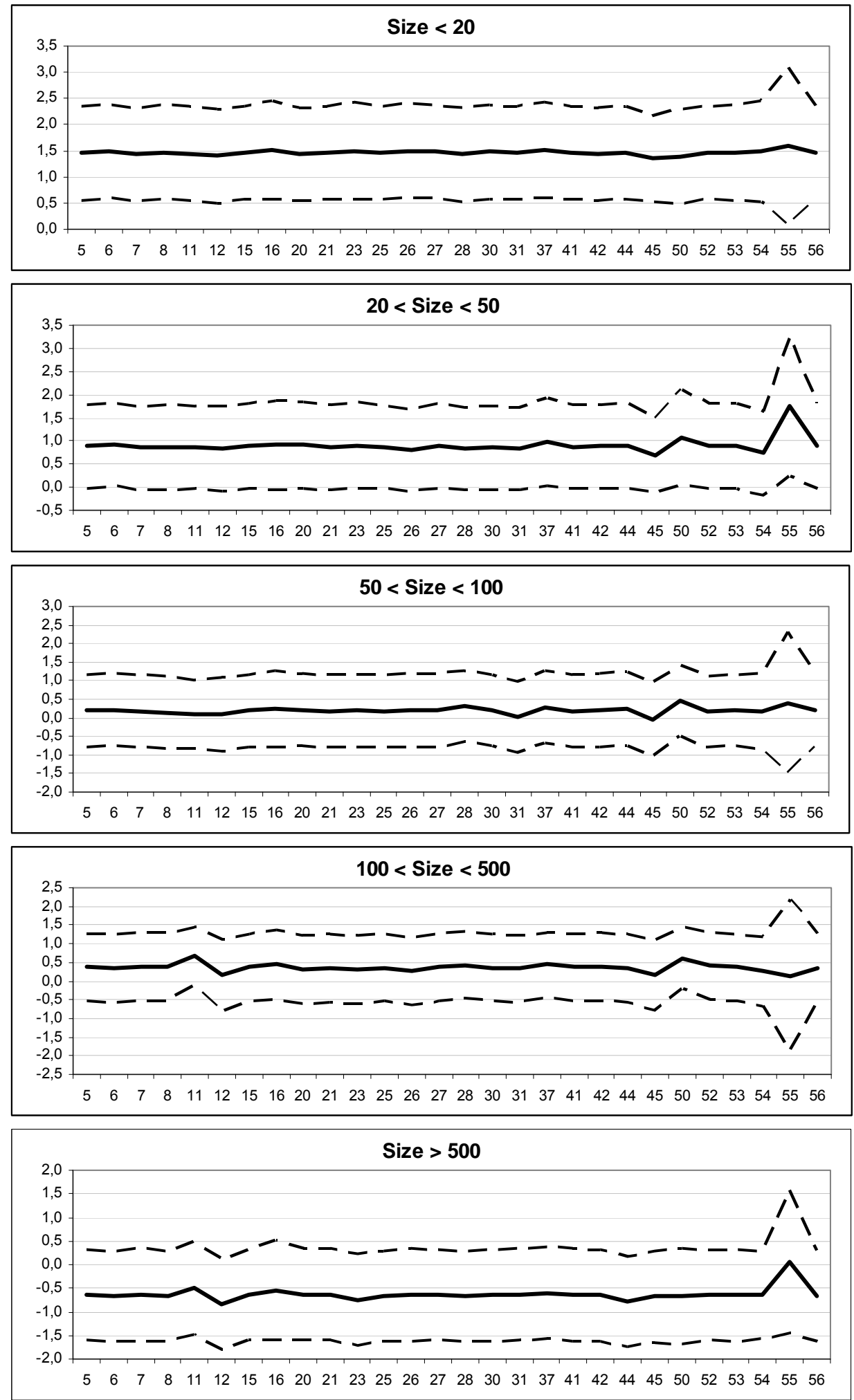

[ISIC Rev.3 sectors used in our analysis: 5 Food - 6 Textiles - 7 Wood - 8 Paper - 11 Petroleum - 12 Chemicals - 15 Plastics - 16 Other non-metallic - 20 Basic metals - 21 Metal products - 23 Machinery - 25 Office - 26 Electrical - 27 Radio TV - 28 Precision - 30 Motor vehicles - 31 Other - 37 Construction - 41 Trade and repairs - 42 Hotels and restaurants - 44 Transport - 45 Post and telecom - 50 Related to financial intermediation - 52 Real estate - 53 Renting - 54 Computer - 55 R\&D - 56 Other business] 
Table 1 - Data sources

\begin{tabular}{|c|c|c|c|c|c|}
\hline Country & Source & Period* & Sectors & $\begin{array}{l}\text { Availability of } \\
\text { survival data }\end{array}$ & Threshold \\
\hline Denmark & Business register & $89-94$ & All sectors & no & emp $\geq 1$ \\
\hline France & Fiscal database & $90-97$ & All sectors & yes & $\begin{array}{l}\text { Turnover: Man: 0.58M€ } \\
\text { Serv: } 0.17 \mathrm{M} €\end{array}$ \\
\hline Italy & Social security & $89-94$ & All sectors & yes & emp $\geq 1$ \\
\hline Netherlands & Business register & $89-97$ & All sectors & no & none \\
\hline Finland & Business register & $89-98$ & All sectors & yes & emp $\geq 1$ \\
\hline Germany (West) & Social security & $89-99$ & $\begin{array}{l}\text { All but civil service, } \\
\text { self employed }\end{array}$ & yes & emp $\geq 1$ \\
\hline Portugal & Employment-based register & $89-98$ & $\begin{array}{l}\text { All but public } \\
\text { administration }\end{array}$ & yes & emp $\geq 1$ \\
\hline UK & Business register & $89-98$ & Manufacturing & yes & emp $\geq 1$ \\
\hline USA & Business register & $89-97$ & Private businesses & yes & emp $\geq 1$ \\
\hline Chile & Annual Industry Survey (ENIA) & $89-99$ & Manufacturing & yes & $\mathrm{emp} \geq 10$ \\
\hline Colombia & $\begin{array}{l}\text { Annual Manufacturing survey } \\
\text { (EAM) }\end{array}$ & $89-98$ & Manufacturing & yes & $\mathrm{emp} \geq 10$ \\
\hline Mexico & Social security & $89-99$ & All sectors & yes & emp $\geq 1$ \\
\hline Slovenia & Business register & $96-99$ & All sectors & yes & emp $\geq 1$ \\
\hline Hungary & Fiscal register (APEH) & $96-99$ & All sectors & yes & emp $\geq 1$ \\
\hline Romania & Business register & $96-99$ & All sectors & yes & emp $\geq 1$ \\
\hline Argentina & $\begin{array}{l}\text { Register, based on Integrated } \\
\text { System of Pensions }\end{array}$ & $95-99$ & All sectors & yes & emp $\geq 1$ \\
\hline
\end{tabular}

${ }^{*}$ We only consider entry rates after 1996 for transition countries. For survival data, the time coverage may differ for some countries

Table 2: Entry rates, analysis of variance

\begin{tabular}{lll}
\hline \hline & Total economy & Total manufacturing \\
\hline Industry effects & $3.3 \%$ & $0.4 \%$ \\
Country effects & $6.5 \%$ & $8.5 \%$ \\
Size effects & $36.7 \%$ & $33.6 \%$ \\
Industry*size effects & $43.2 \%$ & $34.7 \%$ \\
\hline \hline
\end{tabular}

Notes: Adjusted R-squared of fixed effects regressions on average (employmentweighted) entry rates over the 1990s.

Sources: Authors' calculation. 
Table 3: Country variables (used for entry regressions*)

\begin{tabular}{llllll}
\hline \hline Country & $\begin{array}{l}\text { Financial } \\
\text { development }\end{array}$ & $\begin{array}{l}\text { Private } \\
\text { Credit }\end{array}$ & $\begin{array}{l}\text { Stock } \\
\text { Market }\end{array}$ & $\begin{array}{l}\text { Employment } \\
\text { protection } \\
\text { legislation }\end{array}$ & $\begin{array}{l}\text { Cost of } \\
\text { Entry }\end{array}$ \\
\hline Denmark & 0,73 & 0,43 & 0,30 & 0,52 & 0,37 \\
France & 1,22 & 0,91 & 0,31 & 0,66 & 0,66 \\
Italy & 0,70 & 0,56 & 0,14 & 0,65 & 0,59 \\
Netherlands & 2,36 & 1,57 & 0,79 & 0,59 & 0,25 \\
Finland & 1,04 & 0,76 & 0,28 & 0,65 & 0,15 \\
Germany & 1,29 & 1,00 & 0,29 & 0,64 & 0,50 \\
Portugal & 0,83 & 0,64 & 0,20 & 0,54 & 0,57 \\
UK & 2,26 & 1,11 & 1,15 & 0,28 & 0,19 \\
USA & 1,80 & 1,08 & 0,71 & 0,25 & 0,16 \\
Chile & 1,27 & 0,54 & 0,73 & 0,47 & 0,35 \\
Colombia & 0,37 & 0,26 & 0,11 & 0,52 & 0,74 \\
Mexico & 0,51 & 0,22 & 0,29 & 0,37 & 0,58 \\
Slovenia & 0,34 & 0,27 & 0,07 & 0,64 & 0,43 \\
Hungary & 0,46 & 0,22 & 0,23 & 0,44 & 0,26 \\
Romania & 0,10 & 0,08 & 0,01 & 0,37 & 0,64 \\
Argentina & 0,40 & 0,22 & 0,18 & 0,41 & 0,38 \\
\hline Mean & 0,98 & 0,62 & 0,36 & 0,50 & 0,43 \\
Standard deviation & 0,68 & 0,42 & 0,31 & 0,14 & 0,19 \\
\hline \hline
\end{tabular}

Notes:For post-entry growth regressions, the time coverage may differ for some countries; therefore, the averages of reported indicators of financial development are slightly different.

Sources: Authors'calculation.

Table 4._ Entry rate regressions, average impact of financial development

\begin{tabular}{|c|c|c|c|}
\hline & (1) & $\begin{array}{c}\text { Entry rate } \\
\text { (2) }\end{array}$ & (3) \\
\hline $\begin{array}{l}\text { FD } \\
{ }^{*} \text { ExtDep }\end{array}$ & $\begin{array}{c}0.625 \\
{[0.231]^{\star * *}}\end{array}$ & & \\
\hline $\begin{array}{l}\text { Credit } \\
{ }^{*} \text { ExtDep }\end{array}$ & & $\begin{array}{c}1.068 \\
{[0.385]^{\star * *}}\end{array}$ & \\
\hline $\begin{array}{l}\text { Stock } \\
{ }^{*} \text { ExtDep }\end{array}$ & & & $\begin{array}{c}1.048 \\
{[0.514]^{* *}}\end{array}$ \\
\hline Observations & 10169 & 10169 & 10169 \\
\hline R-squared & 0.31 & 0.31 & 0.31 \\
\hline
\end{tabular}

Interactions with the dependence in external finance (source: Klapper et al. 2006)

OLS regressions; robust standard errors in brackets; year dummies, size specific country and industry dummies; clusters by country/industry;

* significant at $10 \%$; ${ }^{* *}$ significant at $5 \%$; ${ }^{* * *}$ significant at $1 \%$ 
Table 5. Entry rate regressions, impact of financial development by size

\begin{tabular}{|c|c|c|c|c|c|c|c|}
\hline & $(1)$ & (2) & (3) & $\begin{array}{c}\text { Entry rate } \\
(4)\end{array}$ & (5) & (6) & $(7)$ \\
\hline $\begin{array}{l}\text { FD } \\
\text { *ExtDep * s1 }\end{array}$ & $\begin{array}{c}1.461 \\
{[0.447]^{\star \star *}}\end{array}$ & & & & & & \\
\hline $\begin{array}{l}\text { FD } \\
{ }^{*} \text { ExtDep * s2 }\end{array}$ & $\begin{array}{c}0.887 \\
{[0.455]^{*}}\end{array}$ & & & & & & \\
\hline $\begin{array}{l}\text { FD } \\
* \text { Fythen * } 3\end{array}$ & 0.194 & & & & & & \\
\hline${ }^{*}$ ExtDep * s3 & {$[0.485]$} & & & & & & \\
\hline $\begin{array}{l}\text { FD } \\
{ }^{*} \text { ExtDep * s4 }\end{array}$ & $\begin{array}{c}0.364 \\
{[0.448]}\end{array}$ & & & & & & \\
\hline $\begin{array}{l}\text { FD } \\
{ }^{*} \text { ExtDep * s5 }\end{array}$ & $\begin{array}{l}-0.642 \\
{[0.484]}\end{array}$ & & & & & & \\
\hline $\begin{array}{l}\text { Credit } \\
{ }^{*} \text { ExtDep * } 1\end{array}$ & & $\begin{array}{c}2.679 \\
{[0.757]^{* * *}}\end{array}$ & & $\begin{array}{c}2.525 \\
{[0.942]^{* * *}}\end{array}$ & & $\begin{array}{c}3.574 \\
{[1.872]^{*}}\end{array}$ & \\
\hline $\begin{array}{l}\text { Credit } \\
\quad \text { * ExtDep * s2 }\end{array}$ & & $\begin{array}{c}1.339 \\
{[0.644]^{\star *}}\end{array}$ & & $\begin{array}{c}1.871 \\
{[0.991]^{*}}\end{array}$ & & $\begin{array}{c}3.842 \\
{[1.262]^{\star \star \star}}\end{array}$ & \\
\hline $\begin{array}{l}\text { Credit } \\
\quad \text { * ExtDep * s3 }\end{array}$ & & $\begin{array}{c}0.618 \\
{[0.770]}\end{array}$ & & $\begin{array}{c}0.646 \\
{[0.942]}\end{array}$ & & $\begin{array}{c}1.960 \\
{[1.987]}\end{array}$ & \\
\hline $\begin{array}{l}\text { Credit } \\
\quad \text { * ExtDep * s4 }\end{array}$ & & $\begin{array}{c}0.404 \\
{[0.754]}\end{array}$ & & $\begin{array}{l}-0.324 \\
{[0.819]}\end{array}$ & & $\begin{array}{c}0.843 \\
{[1.649]}\end{array}$ & \\
\hline $\begin{array}{l}\text { Credit } \\
\quad \text { * ExtDep * s5 }\end{array}$ & & $\begin{array}{c}-1.480 \\
{[0.779]^{\star}}\end{array}$ & & $\begin{array}{l}-1.126 \\
{[0.925]}\end{array}$ & & $\begin{array}{l}-2.748 \\
{[2.280]}\end{array}$ & \\
\hline $\begin{array}{l}\text { Stock } \\
{ }^{*} \text { ExtDep * s1 }\end{array}$ & & & $\begin{array}{c}2.064 \\
{[0.994]^{* *}}\end{array}$ & & $\begin{array}{c}2.731 \\
{[1.366]^{* *}}\end{array}$ & & $\begin{array}{c}4.521 \\
{[1.897]^{* *}}\end{array}$ \\
\hline $\begin{array}{l}\text { Stock } \\
\quad{ }^{*} \text { ExtDep * s2 }\end{array}$ & & & $\begin{array}{c}1.881 \\
{[1.091]^{*}}\end{array}$ & & $\begin{array}{c}2.030 \\
{[1.144]^{*}}\end{array}$ & & $\begin{array}{c}2.942 \\
{[1.704]^{*}}\end{array}$ \\
\hline $\begin{array}{l}\text { Stock } \\
\text { * ExtDep * s3 }\end{array}$ & & & $\begin{array}{l}-0.423 \\
{[1.240]}\end{array}$ & & $\begin{array}{c}0.156 \\
{[1.185]}\end{array}$ & & $\begin{array}{c}1.240 \\
{[1.855]}\end{array}$ \\
\hline $\begin{array}{l}\text { Stock } \\
\text { * ExtDep * s4 }\end{array}$ & & & $\begin{array}{c}1.118 \\
{[1.000]}\end{array}$ & & $\begin{array}{c}0.424 \\
{[1.063]}\end{array}$ & & $\begin{array}{l}1.790 \\
{[1.608]}\end{array}$ \\
\hline $\begin{array}{l}\text { Stock } \\
{ }^{*} \text { ExtDep * s5 }\end{array}$ & & & $\begin{array}{l}-0.228 \\
{[1.254]}\end{array}$ & & $\begin{array}{l}-0.719 \\
{[1.175]}\end{array}$ & & $\begin{array}{l}-2.240 \\
{[1.813]}\end{array}$ \\
\hline $\begin{array}{l}\text { Measures of financial } \\
\text { development: }\end{array}$ & $\begin{array}{r}\text { Outcome var } \\
\mathrm{m}\end{array}$ & $\begin{array}{l}\text { oles (private } \\
\text { ket over GD }\end{array}$ & dit or stock & $\begin{array}{r}\text { Instrumen } \\
\text { var }\end{array}$ & $\begin{array}{l}\text { by policy } \\
\text { es }\end{array}$ & $\begin{array}{r}\text { Simple av } \\
\text { va }\end{array}$ & $\begin{array}{l}\text { e of policy } \\
\text { les }\end{array}$ \\
\hline Observations & 10169 & 10169 & 10169 & 10169 & 10169 & 10169 & 10169 \\
\hline R-squared & 0.31 & 0.31 & 0.31 & 0.31 & 0.31 & 0.31 & 0.31 \\
\hline
\end{tabular}

Variables of financial development: (1) "FD": sum of credit and stock; (2) "Credit": domestic credit to private sector over GDP; (3) "Stock": stock market capitalization over GDP; (4) Credit instrumented by the share of governement banks, barriers to foreign entry in banking, entry requirements, regulation of banking activity; (5) Stock instrumented by contract enforcement, creditor rights, private or public registries, investor protection, bankrupty procedures; (6) Simple average of Credit sub-indices; (7) Simple average of Stock subindices

Interactions with the dependence in external finance (source: Klapper Leaven Rajan, 2006)

OLS regressions; robust standard errors in brackets; year dummies, size specific country and industry dummies; clusters by country/industry;

${ }^{*}$ significant at $10 \% ;{ }^{* *}$ significant at $5 \% ;{ }^{* * *}$ significant at $1 \%$ 
Table 6. Entry rate regressions, controlling for other policy variables

\begin{tabular}{|c|c|c|c|c|c|c|}
\hline & \multicolumn{6}{|c|}{ Entry rate } \\
\hline & $(1)$ & (2) & (3) & (4) & (5) & (6) \\
\hline Credit & 2.692 & & 2.543 & & 2.864 & \\
\hline${ }^{*}$ ExtDep * s1 & {$[1.063]^{\star *}$} & & {$[1.059]^{\star *}$} & & [1.994] & \\
\hline Credit & 2.344 & & 2.036 & & 4.136 & \\
\hline${ }^{*}$ ExtDep * s2 & {$[1.151]^{\star *}$} & & {$[1.093]^{*}$} & & {$[1.881]^{* *}$} & \\
\hline Credit & 1.291 & & 0.843 & & 0.705 & \\
\hline${ }^{*}$ ExtDep * s3 & [1.022] & & [1.082] & & [2.005] & \\
\hline Credit & -0.432 & & -0.890 & & -2.603 & \\
\hline${ }^{*}$ ExtDep * s4 & [0.779] & & [0.904] & & [1.948] & \\
\hline Credit & -0.969 & & -1.508 & & -0.360 & \\
\hline${ }^{*}$ ExtDep * s5 & [1.170] & & [1.096] & & [1.584] & \\
\hline Stock & & 3.218 & & 3.043 & & 1.659 \\
\hline${ }^{*}$ ExtDep * s1 & & [2.174] & & [2.148] & & [3.478] \\
\hline Stock & & 3.456 & & 3.002 & & 5.911 \\
\hline${ }^{*}$ ExtDep * s2 & & {$[1.810]^{*}$} & & {$[1.761]^{\star}$} & & {$[2.944]^{\star *}$} \\
\hline Stock & & 1.211 & & 0.481 & & 0.718 \\
\hline${ }^{*}$ ExtDep * s3 & & [1.946] & & [1.985] & & [2.884] \\
\hline Stock & & -0.459 & & -1.141 & & -3.425 \\
\hline${ }^{*}$ ExtDep * s4 & & [1.227] & & [1.348] & & [3.003] \\
\hline Stock & & -1.031 & & -2.032 & & -0.698 \\
\hline${ }^{*}$ ExtDep * s5 & & [2.373] & & [2.388] & & [2.736] \\
\hline EPL & -0.934 & -0.891 & & & & \\
\hline * JobflowsUS * s1 & [0.573] & {$[0.575]$} & & & & \\
\hline EPL & -1.277 & -1.259 & & & & \\
\hline * JobflowsUS * s2 & {$[0.597]^{\star \star}$} & {$[0.599]^{\star *}$} & & & & \\
\hline EPL & -1.451 & -1.423 & & & & \\
\hline * JobflowsUS * s3 & {$[0.636]^{\star \star}$} & {$[0.638]^{\star *}$} & & & & \\
\hline EPL & -1.218 & -1.228 & & & & \\
\hline * JobflowsUS * s4 & {$[0.698]^{*}$} & {$[0.699]^{*}$} & & & & \\
\hline EPL & -1.004 & -1.026 & & & & \\
\hline * JobflowsUS * s5 & {$[0.476]^{* *}$} & {$[0.473]^{\star *}$} & & & & \\
\hline Entry cost & & & 0.364 & 0.349 & & \\
\hline${ }^{*}$ TurnoverUS * s1 & & & [0.412] & [0.414] & & \\
\hline Entry cost & & & 0.336 & 0.337 & & \\
\hline${ }^{*}$ TurnoverUS * s2 & & & [0.220] & [0.223] & & \\
\hline Entry cost & & & 0.379 & 0.365 & & \\
\hline${ }^{*}$ TurnoverUS * s3 & & & [0.271] & [0.274] & & \\
\hline Entry cost & & & 0.025 & 0.026 & & \\
\hline${ }^{*}$ TurnoverUS * s4 & & & [0.278] & [0.278] & & \\
\hline Entry cost & & & -0.024 & -0.023 & & \\
\hline${ }^{*}$ TurnoverUS * s5 & & & [0.426] & [0.428] & & \\
\hline Entry cost & & & & & -0.427 & -0.465 \\
\hline${ }^{*}$ RdlvaUS * s1 & & & & & [0.416] & [0.412] \\
\hline Entry cost & & & & & -0.349 & -0.358 \\
\hline${ }^{*}$ RdlvaUS * s2 & & & & & {$[0.252]$} & [0.255] \\
\hline Entry cost & & & & & 0.218 & 0.212 \\
\hline${ }^{*}$ RdlvaUS * s3 & & & & & [0.379] & [0.378] \\
\hline Entry cost & & & & & -0.787 & -0.779 \\
\hline${ }^{*}$ RdlvaUS * s4 & & & & & {$[0.536]$} & [0.535] \\
\hline Entry cost & & & & & -1.201 & -1.203 \\
\hline${ }^{*}$ RdlvaUS * s5 & & & & & {$[0.507]^{* *}$} & {$[0.504]^{\star *}$} \\
\hline Observations & 9189 & 9189 & 9189 & 9189 & 9034 & 9034 \\
\hline R-squared & 0.30 & 0.30 & 0.30 & 0.30 & 0.30 & 0.30 \\
\hline
\end{tabular}

Variables of financial development: Credit or Stock instrumented by policy variables; Other variables: EPL: employment protection legislation; Entrycost: difficulty to start a business;

Interactions with the dependence in external finance, jobflows in US, Turnover rates in US, Relative growth of the sector in US;

OLS regressions; robust standard errors in brackets; year dummies, size specific country and industry dummies; clusters by country/industry;

${ }^{*}$ significant at $10 \% ;{ }^{* *}$ significant at $5 \% ;{ }^{* * *}$ significant at $1 \%$ 
Table 7. Post-entry growth regressions, impact of financial development

\begin{tabular}{|c|c|c|c|c|c|c|c|}
\hline & \multicolumn{7}{|c|}{ Post-entry growth } \\
\hline & (1) & (2) & (3) & (4) & (5) & (6) & (7) \\
\hline $\begin{array}{l}\text { FD } \\
{ }^{*} \text { ExtDep }\end{array}$ & $\begin{array}{c}0.251 \\
{[0.091]^{\star \star \star}}\end{array}$ & & & & & & \\
\hline $\begin{array}{l}\text { Credit } \\
{ }^{*} \text { ExtDep }\end{array}$ & & $\begin{array}{c}0.392 \\
{[0.145]^{\star * *}}\end{array}$ & & $\begin{array}{c}0.446 \\
{[0.169]^{\star * *}}\end{array}$ & & $\begin{array}{c}0.569 \\
{[0.264]^{* *}}\end{array}$ & \\
\hline $\begin{array}{l}\text { Stock } \\
{ }^{*} \text { ExtDep }\end{array}$ & & & $\begin{array}{c}0.462 \\
{[0.255]^{*}}\end{array}$ & & $\begin{array}{c}0.617 \\
{[0.239]^{\star *}}\end{array}$ & & $\begin{array}{c}0.880 \\
{[0.343]^{\star *}}\end{array}$ \\
\hline $\begin{array}{l}\text { Measure of financial } \\
\text { development: }\end{array}$ & Outcome va & $\begin{array}{l}\text { les (private } \\
\text { ket over G }\end{array}$ & dit or stock & $\begin{array}{r}\text { Instrume } \\
\text { va }\end{array}$ & $\begin{array}{l}\text { by policy } \\
\text { es }\end{array}$ & $\begin{array}{r}\text { Simple av } \\
\text { va }\end{array}$ & $\begin{array}{l}\text { e of policy } \\
\text { es }\end{array}$ \\
\hline Observations & 319 & 319 & 319 & 319 & 319 & 319 & 319 \\
\hline R-squared & 0.32 & 0.32 & 0.31 & 0.32 & 0.32 & 0.31 & 0.32 \\
\hline
\end{tabular}

Dependent variable: increase in the average employment among new surviving firms after the initial six years of life.

Variables of financial development: (1) "FD": sum of credit and stock; (2) "Credit": domestic credit to private sector over GDP; (3) "Stock": stock market capitalization over GDP; (4) Credit instrumented by the share of governement banks, barriers to foreign entry in banking, entry requirements, regulation of banking activity; (5) Stock instrumented by contract enforcement, creditor rights, private or public registries, investor protection, bankrupty procedures; (6) Simple average of Credit sub-indices; (7) Simple average of Stock sub-indices

Interactions with the dependence in external finance (source: Klapper Leaven Rajan, 2006)

OLS regressions; robust standard errors in brackets; country and industry dummies included;

* significant at $10 \%$; ${ }^{* *}$ significant at $5 \%$; ${ }^{* * *}$ significant at $1 \%$

Table 8. Post-entry growth regressions, controlling for other policy variables

\begin{tabular}{|c|c|c|c|c|c|c|}
\hline & \multicolumn{6}{|c|}{ Post-entry growth } \\
\hline & (1) & (2) & (3) & (4) & (5) & (6) \\
\hline $\begin{array}{l}\text { Credit } \\
{ }^{*} \text { ExtDep }\end{array}$ & $\begin{array}{c}0.424 \\
{[0.190]^{\star *}}\end{array}$ & & $\begin{array}{c}0.380 \\
{[0.125]^{\star \star \star}}\end{array}$ & & $\begin{array}{c}0.433 \\
{[0.165]^{\star * *}}\end{array}$ & \\
\hline $\begin{array}{l}\text { Stock } \\
{ }^{*} \text { ExtDep }\end{array}$ & & $\begin{array}{c}0.841 \\
{[0.391]^{\star *}}\end{array}$ & & $\begin{array}{c}0.527 \\
{[0.181]^{\star \star \star}}\end{array}$ & & $\begin{array}{c}0.623 \\
{[0.241]^{\star *}}\end{array}$ \\
\hline $\begin{array}{l}\text { EPL } \\
\text { * Jobflows US }\end{array}$ & $\begin{array}{c}0.019 \\
{[0.028]}\end{array}$ & $\begin{array}{c}0.020 \\
{[0.029]}\end{array}$ & & & & \\
\hline $\begin{array}{l}\text { Size at } \\
\text { entry }\end{array}$ & & & $\begin{array}{c}-0.214 \\
{[0.047]^{\star \star *}}\end{array}$ & $\begin{array}{c}-0.214 \\
{[0.046]^{\star * *}}\end{array}$ & & \\
\hline $\begin{array}{l}\text { Growth of } \\
\text { all firms }\end{array}$ & & & & & $\begin{array}{c}1.626 \\
{[0.762]^{\star *}}\end{array}$ & $\begin{array}{c}1.645 \\
{[0.763]^{\star *}}\end{array}$ \\
\hline Observations & 291 & 291 & 319 & 319 & 309 & 309 \\
\hline R-squared & 0.33 & 0.33 & 0.42 & 0.42 & 0.35 & 0.35 \\
\hline
\end{tabular}

Dependent variable: increase in the average employment among new surviving firms after the initial six years of life. Variables of financial development: Credit or Stock instrumented by policy variables; Other variables: EPL: employment protection legislation; Entrycost: difficulty to start a business;

Interactions with the dependence in external finance and jobflows in US (in the later case, US is dropped from the regressions)

OLS regressions; robust standard errors in brackets; country and industry dummies included;

* significant at $10 \%$; ${ }^{* *}$ significant at $5 \%$; *** significant at $1 \%$ 
Table 9: Entry rates regressions, sensitivity analysis

\begin{tabular}{|c|c|c|c|c|c|c|}
\hline & \multicolumn{6}{|c|}{ Entry rate } \\
\hline & (1) & (2) & (3) & (4) & (5) & (6) \\
\hline Industry share & $\begin{array}{c}-0.736 \\
{[0.126]^{\star \star \star}}\end{array}$ & $\begin{array}{c}-0.743 \\
{[0.125]^{\star \star *}}\end{array}$ & & & & \\
\hline Relative growth of VA & & & $\begin{array}{c}0.303 \\
{[0.274]}\end{array}$ & $\begin{array}{c}0.302 \\
{[0.274]}\end{array}$ & & \\
\hline $\begin{array}{l}\text { Credit } \\
{ }^{*} \text { ExtDep * } 11\end{array}$ & $\begin{array}{c}2.527 \\
{[0.925]^{\star \star *}}\end{array}$ & & $\begin{array}{c}3.164 \\
{[1.190]^{\star \star \star}}\end{array}$ & & & \\
\hline $\begin{array}{l}\text { Credit } \\
{ }^{*} \text { ExtDep * s2 }\end{array}$ & $\begin{array}{c}1.732 \\
{[1.031]^{*}}\end{array}$ & & $\begin{array}{c}3.026 \\
{[1.090]^{\star * *}}\end{array}$ & & & \\
\hline $\begin{array}{l}\text { Credit } \\
{ }^{*} \text { ExtDep * } 33\end{array}$ & $\begin{array}{c}0.451 \\
{[0.911]}\end{array}$ & & $\begin{array}{c}0.476 \\
{[1.206]}\end{array}$ & & & \\
\hline $\begin{array}{l}\text { Credit } \\
\text { * ExtDep * s4 }\end{array}$ & $\begin{array}{l}-0.552 \\
{[0.799]}\end{array}$ & & $\begin{array}{l}-0.538 \\
{[1.225]}\end{array}$ & & & \\
\hline $\begin{array}{l}\text { Credit } \\
\text { * ExtDep * s5 }\end{array}$ & $\begin{array}{l}-0.421 \\
{[1.053]}\end{array}$ & & $\begin{array}{c}-2.790 \\
{[1.457]^{*}}\end{array}$ & & & \\
\hline $\begin{array}{l}\text { Stock } \\
{ }^{*} \text { ExtDep * s1 }\end{array}$ & & $\begin{array}{c}2.966 \\
{[1.279]^{* *}}\end{array}$ & & $\begin{array}{c}3.635 \\
{[2.090]^{*}}\end{array}$ & & \\
\hline $\begin{array}{l}\text { Stock } \\
\text { * ExtDep * s2 }\end{array}$ & & $\begin{array}{c}1.977 \\
{[1.212]}\end{array}$ & & $\begin{array}{c}3.295 \\
{[1.499]^{* *}}\end{array}$ & & \\
\hline $\begin{array}{l}\text { Stock } \\
\text { * ExtDep * s3 }\end{array}$ & & $\begin{array}{c}0.074 \\
{[1.154]}\end{array}$ & & $\begin{array}{c}0.018 \\
{[1.710]}\end{array}$ & & \\
\hline $\begin{array}{l}\text { Stock } \\
\text { * ExtDep * s4 }\end{array}$ & & $\begin{array}{c}0.325 \\
{[1.149]}\end{array}$ & & $\begin{array}{l}-0.529 \\
{[1.535]}\end{array}$ & & \\
\hline $\begin{array}{l}\text { Stock } \\
{ }^{*} \text { ExtDep * s5 }\end{array}$ & & $\begin{array}{l}-0.281 \\
{[1.213]}\end{array}$ & & $\begin{array}{l}-2.067 \\
{[2.102]}\end{array}$ & & \\
\hline $\begin{array}{l}\text { Credit } \\
{ }^{*} \text { RdlvaUS * } 1\end{array}$ & & & & & $\begin{array}{c}0.450 \\
{[0.205]^{\star *}}\end{array}$ & \\
\hline $\begin{array}{l}\text { Credit } \\
{ }^{*} \text { RdlvaUS * s2 }\end{array}$ & & & & & $\begin{array}{c}0.593 \\
{[0.200]^{\star * *}}\end{array}$ & \\
\hline $\begin{array}{l}\text { Credit } \\
\text { * RdlvaUS * s3 }\end{array}$ & & & & & $\begin{array}{c}0.493 \\
{[0.273]^{\star}}\end{array}$ & \\
\hline $\begin{array}{l}\text { Credit } \\
\text { * RdlvaUS * s4 }\end{array}$ & & & & & $\begin{array}{l}-0.202 \\
{[0.327]}\end{array}$ & \\
\hline $\begin{array}{l}\text { Credit } \\
{ }^{*} \text { RdlvaUS * s5 }\end{array}$ & & & & & $\begin{array}{l}-0.153 \\
{[0.190]}\end{array}$ & \\
\hline $\begin{array}{l}\text { Stock } \\
\text { * RdlvaUS * s1 }\end{array}$ & & & & & & $\begin{array}{c}0.752 \\
{[0.317]^{\star *}}\end{array}$ \\
\hline $\begin{array}{l}\text { Stock } \\
{ }^{*} \text { RdlvaUS * s2 }\end{array}$ & & & & & & $\begin{array}{c}0.581 \\
{[0.317]^{*}}\end{array}$ \\
\hline $\begin{array}{l}\text { Stock } \\
{ }^{*} \text { RdlvaUS * s3 }\end{array}$ & & & & & & $\begin{array}{c}0.478 \\
{[0.339]}\end{array}$ \\
\hline $\begin{array}{l}\text { Stock } \\
{ }^{*} \text { RdlvaUS * s4 }\end{array}$ & & & & & & $\begin{array}{l}-0.391 \\
{[0.440]}\end{array}$ \\
\hline $\begin{array}{l}\text { Stock } \\
{ }^{*} \text { RdlvaUS * s5 }\end{array}$ & & & & & & $\begin{array}{l}-0.037 \\
{[0.322]}\end{array}$ \\
\hline Observations & 10169 & 10169 & 8797 & 8797 & 9034 & 9034 \\
\hline R-squared & 0.32 & 0.32 & 0.31 & 0.31 & 0.30 & 0.30 \\
\hline
\end{tabular}

Variables of financial development: Credit or Stock instrumented by policy variables;

Interactions with the dependence in external finance (source: Klapper Leaven Rajan [06]) or the relative growth of valueadded in the US sector (source: STAN);

OLS regressions; robust standard errors in brackets; year dummies, size specific country and industry; clusters by country/industry;

${ }^{*}$ significant at $10 \% ;{ }^{* *}$ significant at $5 \% ;{ }^{* * *}$ significant at $1 \%$ 
Table 10: Post-entry growth regressions, sensitivity analysis

\begin{tabular}{|c|c|c|c|c|c|c|c|c|}
\hline & \multicolumn{2}{|c|}{ Incumbent growth } & \multicolumn{4}{|c|}{$\begin{array}{c}\text { post-entry growth after } 5 \text { post-entry growth after } 3 \\
\text { years } \\
\text { years }\end{array}$} & \multicolumn{2}{|c|}{$\begin{array}{l}\text { Total employment } \\
\text { growth }\end{array}$} \\
\hline & (1) & $(2)$ & (3) & (4) & (5) & (6) & $(7)$ & (8) \\
\hline $\begin{array}{l}\text { Credit } \\
\text { *ExtDep }\end{array}$ & $\begin{array}{c}0.016 \\
{[0.017]}\end{array}$ & & $\begin{array}{c}0.307 \\
{[0.150]^{* *}}\end{array}$ & & $\begin{array}{c}0.177 \\
{[0.119]}\end{array}$ & & $\begin{array}{l}0.270 a \\
{[0.167]}\end{array}$ & \\
\hline $\begin{array}{l}\text { Stock } \\
{ }^{*} \text { ExtDep }\end{array}$ & & $\begin{array}{c}0.020 \\
{[0.023]}\end{array}$ & & $\begin{array}{c}0.383 \\
{[0.216]^{*}}\end{array}$ & & $\begin{array}{c}0.211 \\
{[0.156]}\end{array}$ & & $\begin{array}{c}0.504 \\
{[0.191]^{\star * *}}\end{array}$ \\
\hline Observations & 311 & 311 & 320 & 320 & 321 & 321 & 319 & 319 \\
\hline R-squared & 0.44 & 0.44 & 0.40 & 0.39 & 0.40 & 0.40 & 0.34 & 0.35 \\
\hline
\end{tabular}

Variables of financial development: Credit or Stock instrumented by policy variables;

Interactions with the dependence in external finance (source: Klapper Leaven Rajan [06]);

OLS regressions; robust standard errors in brackets; country and industry dummies included;

a significant at $11 \%$; ${ }^{*}$ significant at $10 \%$; ${ }^{* *}$ significant at $5 \%$; ${ }^{* * *}$ significant at $1 \%$ 